\title{
Dietary Fiber and Availability of Nutrients: A Case Study on Yoghurt as a Food Model
}

\author{
Marina Dello Staffolo, Alicia E. Bevilacqua, \\ María Susana Rodríguez and Liliana Albertengo
}

Additional information is available at the end of the chapter

http://dx.doi.org/10.5772/54031

\section{Introduction}

Dietary fibers are consumed from cereals, fruit and vegetables, but now are also added in purified form to food preparations since the roles of dietary fibers in preventing and treating some diseases have been well documented. Dietary fiber intake in Western countries is currently estimated to be 16.3-43.4 g per person per day [1]. According to current recommendations (Food and Nutrition Board, Institute of Medicine, 2001), the average daily requirement of dietary fiber is $25 \mathrm{~g}$ per day for women younger than $50,21 \mathrm{~g}$ per day for women older than 50; $38 \mathrm{~g}$ per day for men younger than 50, and $30 \mathrm{~g}$ per day for men older than 50 [2].

The addition of dietary fibers to foods confers three different types of benefits. Their nutritional value motivates consumers to eat increased quantities of dietary fibers, which is advised by nutritionists. Their technological properties are of great interest to food manufacturers. Finally, dietary fibers may also be used to upgrade agricultural products and by-products for use as food ingredients. Consequently, both the nutritional value and technological properties of dietary fibers are important in the potential development of a wide range of fiber-enriched foods for example: bakery products, snacks, sauces, drinks, cereals, cookies, dairy products, meat products [3].

Different types of dietary fibers have different structures and chemical compositions, and correspondingly are of varying nutritional and technological interest. Although many studies have confirmed the nutritional benefits of dietary fibers (preventing diabetes mellitus, cardiovascular diseases, various types of cancer, and improving immune functions), the results depend on the types of dietary fibers studied or on the experimental conditions used [3]. The intake of dietary fiber might influence in different ways the absorption of nutrients [4]. With respect to glucose, an increase in the total fiber content of food can delay the glycemic response 
[5]. However, there is fairly consistent evidence that soluble types of fiber reduce blood glucose and purified insoluble fibers have little or no effect on postprandial blood glucose [6]. In the other direction, dietary fiber has been shown to impair the absorption of minerals and trace elements in the small intestine because of their binding and/or sequestering effects [7]. This is associated with negative impacts on mineral bioavailability, particularly in high-risk population groups [8]. Glucose, calcium and iron have gained increasing interest in nutrition fields. Glucose is the key in carbohydrate and lipid metabolism influencing the management of body weight [9]. Calcium is involved in most metabolic processes and the phosphate salts of which provide mechanical rigidity to the bones and teeth. Intake of calcium is related to the prevention of osteoporosis [10,11]. Iron (Fe) deficiency is a leading nutritional concern worldwide, affecting $20-50 \%$ of the world's population [12].

There is an unequivocal need for predicting absorption of these nutrients. The aim of most of the investigations in this field is to make evident that fiber may be an important determinant of the utilisation of these nutrients in the diet. Much research has been done to better understand the physicochemical interactions between dietary fiber and these nutrients in the past decades [13-15]. Several of these investigations have applied in vitro digestive models to study their absorption in foods [16-18]. However, few works have been done to study their absorption from fermented milk products [19]. Yogurt is one of the dairy products, which should continue to increase in sales due to acceptance for the consumers and diversification in the range of yogurt-like products, including reduced fat content yogurts, yogurts with dietary fibers, probiotic yogurts, symbiotic yogurts, yogurt ice-cream, etc [20]. For a long time, yogurt has been recognised as a healthy food and as an important nutritional source [21].

The interactions between fibers added to yogurt from different sources (animal and plant fibers) and with different behaviors (soluble, insoluble and viscous fibers) and glucose, calcium and iron, have been studied using chemical experimental models of the human digestive tract to evaluate the availability of these nutrients.

\section{Definition and composition of dietary fiber}

The term 'dietary fiber' (DF) first appeared in 1953 and referred to hemicelluloses, cellulose and lignin [22]. Since the 1970s it has been recognised as having health benefits. Burkitt [23] recommended that individuals should increase their DF intake in order to increase their stool volume and stool softness. This was based on comparisons between Africa and the UK concerning fiber intakes and disease incidence. Trowell [24] first defined DF as 'the remnants of the plant cell wall that are not hydrolysed by the alimentary enzymes of man'. From those days the definition has undergone numerous revisions that were summarized accurately by Tungland and Meyer [4].

The Codex Alimentarius Commission adopted a new definition of fiber in July 2009, designed to harmonize the use of the term around the world. It describes fiber as elements not hydrolised by endogenous enzymes in the small intestine (indigestibility) as well as having physiological effects beneficial to health. Dietary fibers are carbohydrate polymers with ten or more monomeric units and belonging to one of three categories of carbohydrates 
polymers: edible carbohydrate polymers naturally occurring in food, carbohydrate polymers which have been obtained from raw food material by physical, enzymatic, or chemical means, and synthetic carbohydrate polymers [25-27].

The chemical nature of fibers is complex; dietary fibers are constituted of a mixture of chemical entities [28]. Dietary fiber is composed of nondigestible carbohydrate, lignin and other associated substances of plant origin, fibers of animal origin and modified or synthetic nondigestible carbohydrate polymers. The nondigestible carbohydrates are composed of the following polysaccharides: cellulose, $\beta$-glucan, hemicelluloses, gums, mucilage, pectin, inulin, resistant starch; oligosaccharides: fructo-oligosaccharides, oligofructose, polydextrose, galacto-oligosaccharides; and soybean oligosaccharides raffinose and stachyose [4]. Chitosan is an example of fiber of animal origin, derived from the chitin contained in the exoskeletons of crustaceans and squid pens; its molecular structure is similar to that of plant cellulose [29]. Cereals are the principal source of cellulose, lignin and hemicelluloses, whereas fruits and vegetables are the primary sources of pectin, gums and mucilage [30]. Each polysaccharide is characterised by its sugar residues and by the nature of the bond between them [28]. They are presented in Table 1.

\begin{tabular}{|c|c|c|}
\hline Fibers & Main chain & Branch units \\
\hline Cellulose & $\beta-(1,4)$ glucose & \\
\hline$\beta$-glucans & $\beta$ - $(1,4)$ glucose and $\beta-(1,3)$ glucose & \\
\hline Hemicelluloses & & \\
\hline Xylans & $\beta$-D- $(1,4)$ xylose & \\
\hline Arabinoxylans & $\beta$-D- $(1,4)$ xylose & Arabinose \\
\hline Mannans & $\beta$-D- $(1,4)$ mannose & \\
\hline Glucomanns & $\beta$-D- $(1,4)$ mannose and $\beta$-D- $(1,4)$ glucose & \\
\hline Galactoglucomannans & $\beta$-D- $(1,4)$ mannose, $\beta$-D- $(1,4)$ glucose & Galactose \\
\hline Galactomannans & $\beta-(1,4)$ mannose & $\alpha$-D-galactose \\
\hline Xyloglucans & $\beta$-D- $(1,4)$ glucose & $\alpha$-D-xylose \\
\hline Pectin & & \\
\hline Homogalacturonan & $\begin{array}{l}\alpha-(1,4)-D \text {-galacturonic acid (some of the } \\
\text { carboxyl groups are methyl esterified) }\end{array}$ & \\
\hline Rhamnogalacturonan-I & $\begin{array}{l}(1,4) \text { galacturonic acid, }(1,2) \text { rhamnose } \\
\text { and 1-, 2-, 4-rhamnose }\end{array}$ & $\begin{array}{l}\text { Galactose, arabinose, } \\
\text { xylose, } \\
\text { rhamnose, galacturonic acid }\end{array}$ \\
\hline Rhamnogalacturonan-II & $\alpha-(1-4)$ galacturonic acid & $\begin{array}{l}\text { Unusual sugar such as: } \\
\text { apiose, aceric acid, fucose }\end{array}$ \\
\hline Arabinans & $\alpha-(1-5)-\mathrm{L}$-arabinofuranose & $\alpha$-arabinose \\
\hline Galactans & $\beta$-(1-4)-D-galactopyranose & \\
\hline Arabinogalactanes-I & $\beta$-(1-4)-D-galactopyranose & $\alpha$-arabinose \\
\hline Arabinogalactanes-II & $\beta$-(1-3)-and $\beta$-(1-6)-D-galactopyranose & $\alpha$-arabinose \\
\hline Xylogalacturonan & $\alpha-(1-4)$ galacturonic acid & xylose \\
\hline $\begin{array}{l}\text { Inulin } \\
\text { Gum }\end{array}$ & $\beta$-(2-1)-D-fructosyl-fructose & \\
\hline Carrageenan & Sulfato-galactose & \\
\hline Alginate & $\begin{array}{l}\beta-(1,4)-\mathrm{D} \text {-mannuronic acid or } \alpha-(1-4)-\mathrm{L}- \\
\text { guluronic acid }\end{array}$ & \\
\hline
\end{tabular}




\begin{tabular}{|c|c|c|}
\hline Fibers & Main chain & Branch units \\
\hline e.g. 1: seed gum from & $\beta$-(1,4)-D-mannose & D- $(1,6)$ galactose \\
\hline \multicolumn{3}{|l|}{ Abutilon indicum } \\
\hline e.g. 2: seed gum from & Rhamnose, arabinose, xylose, Mannose, & \\
\hline Lesquerella fendleri & galactose, glucose, galacturonic acid & \\
\hline $\begin{array}{l}\text { Oligofructose (enzymatic } \\
\text { hydrolysis of inulin) }\end{array}$ & $\beta$-(2-1)-D-fructosyl-fructose & \\
\hline Polydextrose (synthetic) & D-Glucose & \\
\hline $\begin{array}{l}\text { Resistant maltodextrins } \\
\text { (heat and enzymatic } \\
\text { treatment of starch) }\end{array}$ & $\alpha(1-4)-D-G l u c o s e$ & $\alpha(1-6)$-D-Glucose \\
\hline Lignin & $\begin{array}{l}\text { Polyphenols: Syringyl alcohol (S), Guaiacyl } \\
\text { alcohol (G) and p-coumaryl alcohol (H) }\end{array}$ & \\
\hline Chitosan & $\begin{array}{l}\beta-(1-4)-\text { linked D-glucosamine and } \mathrm{N}- \\
\text { acetyl-D-glucosamine }\end{array}$ & \\
\hline
\end{tabular}

Table 1. Chemical composition of dietary fibers [28].

\section{Classification of dietary fiber}

Several different classification systems have been suggested to classify the components of dietary fiber: based on their role in the plant, on their fiber constituents (Table 2), on the type of polysaccharide, on their simulated gastrointestinal solubility, on site of digestion and on products of digestion and physiological classification. However, none is entirely satisfactory, as the limits cannot be absolutely defined. Two very accepted classifications are those which use the concept of solubility in a buffer at a defined $\mathrm{pH}$, and/or the concept of fermentability in an in vitro system using an aqueous enzyme solution representative of human alimentary enzymes. Generally, well fermented fibers are soluble in water, while partially or poorly fermented fibers are insoluble [4]. However, dietary fiber is conventionally classified in two categories according to their water solubility: insoluble dietary fiber (IDF) such as cellulose, part of hemicellulose, and lignin; and soluble dietary fiber (SDF) such as pentosans, pectin, gums, and mucilage [31].

Taking into account the physiological and physicochemical behavior of fibers it could be necessary to add two subcategories among the group of soluble fibers: viscous soluble fibers (such as guar gum, glucomannans, pectins, oat $\beta$-glucan, psyllium, mucilages, etc) and nonviscous soluble fibers (such as lactulose, oligosaccharides, fructo-oligosaccharides, inulin, etc.). Jenkins et al. [6, 32] mentioned the term viscous soluble fiber in their works about fibers and low glycaemic index, blood lipids and coronary heart diseases. Dikeman and Fahey [33] also mentioned the term in their work in which they investigated the viscosity in relation with dietary fiber including definitions and instrumentation, factors affecting viscosity of solutions, and effects on health. Thus, dietary fiber could be classified in soluble (viscous and non viscous) and insoluble fiber. The latter do not form gels due to their water insolubility and fermentation is very limited [34]. However, numerous commercial fibers are available in the market for use in food technology and have both insoluble and soluble fiber components in the same product. This is due to the fact that 
many of these are powders which come from the extraction, concentration and drying of the fiber contained in cereals, fruits and vegetables. Therefore, it might be more appropriate to classify fibers based on their content of soluble and insoluble fractions (Table 3). It is recognised that the physiological and physicochemical effects of dietary fibers depend on the relative amount of individual fiber components, especially as regards the soluble and insoluble fractions [28].

Fractionation of dietary fibers aims to quantify those constituents, to isolate fractions of interest and to eliminate undesirable compounds. Techniques for fractionation of dietary fibers are limited in number. Several researchers have determined the cellulose, hemicelluloses and lignin contents of dietary fibers from different food sources. Claye, Idouraine, and Weber [35] isolated and fractionated insoluble fibers from five different sources. Using cold and hot water extraction, enzymatic and chemical treatment, they obtained four fractions: cellulose, hemicellulose A and B, and lignin. The fractionation methods are varied and were developed according to the material tested. Therefore, there is no global method used. The existing methods described universal techniques of fractionation. Each analyst must modify previously used approaches to develop a method optimal to the material being tested [28].

\begin{tabular}{|c|c|c|}
\hline Fiber Constituents & Principal groupings & Fiber components/sources \\
\hline \multirow{5}{*}{$\begin{array}{l}\text { Nonstarch } \\
\text { polysaccharides \& } \\
\text { oligosaccharide }\end{array}$} & Cellulose & $\begin{array}{l}\text { Cellulose-Plants (vegetables, sugar beet, } \\
\text { various brans) }\end{array}$ \\
\hline & Hemicellulose & $\begin{array}{l}\text { Arabinogalactans, _-glucans, } \\
\text { arabinoxylans, glucuronoxylans, } \\
\text { xyloglucans, galactomannans, pectic } \\
\text { substances. }\end{array}$ \\
\hline & Polyfructoses & Inulin, oligofructans \\
\hline & Gums \& Mucilages & $\begin{array}{l}\text { Seed extracts (galactomannans -guar } \\
\text { and locust bean gum), tree exudates } \\
\text { (gum acacia, gum karaya, gum } \\
\text { tragacanth), algal polysaccharides } \\
\text { (alginates, agar, carrageenan), psyllium }\end{array}$ \\
\hline & Pectins & $\begin{array}{l}\text { Fruits, vegetables, legumes, potato, } \\
\text { sugar beets }\end{array}$ \\
\hline \multirow[t]{3}{*}{ Carbohydrate analogues } & $\begin{array}{l}\text { Resistant starches and } \\
\text { maltodextrins }\end{array}$ & $\begin{array}{l}\text { Various plants, such as maize, pea, } \\
\text { potato }\end{array}$ \\
\hline & Chemical synthesis & $\begin{array}{l}\text { Polydextrose, lactulose, cellulose } \\
\text { derviatives (MC, HPMC) }\end{array}$ \\
\hline & Enzymatic synthesis & $\begin{array}{l}\text { Neosugar or short chain } \\
\text { fructooligosaccharides (FOS), } \\
\text { transgalactooligo collagen, chondroitin } \\
\text { saccharides (TOS), levan, xanthan gum, } \\
\text { oligofructose, xylooligosaccharides } \\
\text { (XOS), guar hydrolyzate, curdlan. }\end{array}$ \\
\hline
\end{tabular}




\begin{tabular}{|c|c|c|}
\hline Fiber Constituents & Principal groupings & Fiber components/sources \\
\hline Lignin & Lignin & Woody plants \\
\hline $\begin{array}{l}\text { Substances associated } \\
\text { with nonstarch } \\
\text { polysaccharides }\end{array}$ & Waxes, cutin, Suberin & Plant fibers \\
\hline Animal origin fibers & $\begin{array}{l}\text { Chitin, chitosan, collagen, } \\
\text { chondroitin }\end{array}$ & Fungi, yeasts, invertebrates \\
\hline
\end{tabular}

Table 2. Dietary fiber constituents [4]

\begin{tabular}{|c|c|c|c|}
\hline Category & Subcategory & Fiber fraction & Main food source \\
\hline \multirow[t]{6}{*}{ Soluble fiber } & \multirow[t]{3}{*}{ Viscous } & $\beta$-glucans & Grains (oat, barley, rye) \\
\hline & & Pectins & $\begin{array}{l}\text { Fruits, vegetables, legumes, sugar } \\
\text { beet, potato }\end{array}$ \\
\hline & & Gums \& Mucilages & $\begin{array}{l}\text { Leguminous seed plants (guar, locust } \\
\text { bean), seaweed extracts (carrageenan, } \\
\text { alginates), plant extracts (gum acacia, } \\
\text { gum karaya, gum tragacanth), } \\
\text { microbial gums (xanthan, gellan), } \\
\text { psylluim }\end{array}$ \\
\hline & \multirow[t]{3}{*}{ Nonviscous } & Sugars & Lactulose \\
\hline & & Oligosaccharides & $\begin{array}{l}\text { Various plants and synthetically } \\
\text { produced (polydextrose, } \\
\text { fructooligosaccharides, } \\
\text { galactooligosaccharides, } \\
\text { transgalactooligosaccharides) }\end{array}$ \\
\hline & & Inulin & $\begin{array}{l}\text { Chicory, Jerusalem artichoke, sugar } \\
\text { beet, onions }\end{array}$ \\
\hline \multirow[t]{7}{*}{ Insoluble fiber } & & Cellulose & Plants (vegetables, various brans) \\
\hline & & Hemicellulose & Cereal grains \\
\hline & & Lignin & Woody plants \\
\hline & & $\begin{array}{l}\text { Cutin/suberin/other } \\
\text { plant waxes }\end{array}$ & Plant fibers \\
\hline & & $\begin{array}{l}\text { Chitin and chitosan, } \\
\text { collagen }\end{array}$ & Fungi, yeasts, invertebrates \\
\hline & & Resistant starches & $\begin{array}{l}\text { Plants (corn, potatoes, grains, } \\
\text { legumes, bananas) }\end{array}$ \\
\hline & & $\begin{array}{l}\text { Curdlan (insoluble } \\
\beta \text {-glucan) }\end{array}$ & Bacterial fermentation \\
\hline
\end{tabular}

Table 3. Table 3. Classification of dietary fiber based on solubility

\section{Analytical methods for studying dietary fibers}

The complexity of fibers is given by their chemical nature and polymerisation degree that they possess. This requires various analytical methods for the measurement of dietary fiber, to precisely estimate its composition in food and food by-products. Methods for the determination of dietary fiber may be divided into three categories: non-enzymatic- 
gravimetric, enzymatic-gravimetric, and enzymatic-chemical methods. The latter includes enzymatic-colorimetric and enzymatic-chromatographic (GLC/ HPLC) methods [28]. Nowadays, the most commonly used methods for dietary fiber measurement are the enzymatic-gravimetric Association of Official Analytical Chemists (AOAC) method [36] and enzymatic-chemical method [37]. The method of Van Soest [38] is generally used in veterinary studies.

\section{Dietary fiber and human health}

\subsection{Fiber, lipid metabolism and cardiovascular disease}

The earliest and most widely researched topic related to dietary fiber and human health is reducing the risk factors for coronary heart disease [24]. Total serum cholesterol and low density- lipoprotein (LDL) cholesterol levels are generally accepted as biomarkers indicating of potential risk for developing the disease [5]. In consequence, research has primarily focused on their reduction as a means to diminish the risk of developing cardiovascular disease. Substantial experimental data support that blood cholesterol can be lowered using viscous soluble fibers that produce relatively high viscosity in the intestinal tract [39-41]. It is known that viscous soluble and insoluble dietary fibers can bind bile acids and micelle components, such as monoglycerides, free fatty acids, and cholesterol, which decrease the absorption and increase the fecal excretion of these entities [42,43]. For insoluble dietary fibers such as lignin or citric fiber this reducing effect is rather low compared to viscous soluble dietary fibers and is mainly based on direct binding of bile acids. In the small intestine the bile acids are bound by the insoluble dietary fibers through hydrophobic interactions and excreted from enterohepatic circulation together with the undigested insoluble dietary fibers which results in a lowering of the blood biomarkers levels $[44,45]$. Furthermore, free fatty acids and cholesterol bound by dietary fibers cannot be absorbed by the body and will be excreted. The biomarkers-lowering effect of viscous soluble dietary fibers such as psyllium, oat $\beta$-glucan or pectin is based on different mechanisms. The binding of water in the chyme and the resulting increase in viscosity is regarded as the main effect. This leads to a reduced diffusion rate of bile acids, which cannot be reabsorbed by the body and thus are excreted [46-48]. Besides, some studies indicate that there are also direct binding forces such as hydrophobic interactions between soluble dietary fibers and bile acids [49]. Dietary fiber also modifies lipid metabolism by influencing the expression of key genes. Acetyl-CoA carboxylase is the rate-limiting enzyme in lipogenesis and is regulated by AMP-activated protein kinase (AMPK). In a 10-week study comparing obese and lean rats, adding $5 \mathrm{~g}$ of $\mathrm{P}$. ovata to rat chow increased the phosphorylation of AMPK, consequently inhibiting acetyl-CoA carboxylase [50]. Fructooligosaccharide $(10 \mathrm{~g} / 100 \mathrm{~g})$ also has been shown to decrease the hepatic acetyl-CoA carboxylase expression in rats [51]. In view of new research [52,34] the United States Food and Drug Administration has approved health claims supporting the role of dietary fiber in the prevention of coronary heart disease [53]. 


\subsection{Fiber, carbohydrate metabolism, and diabetes mellitus}

It is known that exists a link among an elevated body mass index, waist circumference and the risk of type 2 diabetes mellitus [54,55]. The role of DF in weight reduction has been examined in animal and human studies. A reduced risk for type 2 diabetes mellitus (T2DM) appears to depend on the type and dose of dietary fiber and the study population [36]. In mice, $10 \%$ psyllium and $10 \%$ sugar cane fiber decreased the fasting blood glucose and fasting plasma insulin when added to a high fat diet for 12 weeks, compared to the insoluble fiber cellulose [56]. $\beta$-Glucan also improved the glucose tolerance and decreased the serum insulin in mice when added to a high fat diet at a $2 \%$ and $4 \%$ level [57]. In humans, muffins high in $\beta$-glucan and resistant starch lowered the postprandial blood glucose and insulin levels [58]. A prospective cohort design with 252 women was used to measure energy intake, dietary fat intake, fiber intake, body weight, body fat percentage, physical activity, season of assessment, age and time between assessments. They concluded that increasing dietary fiber intake significantly reduced the risk of gaining weight and fat in women, independent of several potential confounders such as: physical activity, dietary fat intake, and others [59]. Another study about the consumption of soluble viscous fiber, that included one hundred and seventy six men and women, reached the same conclusions [60]. Other biomarkers such as Glycemic Index (GI) and Glycemic Load (GL) when they are high were both associated with an increased risk of diabetes in a meta-analysis of observational studies $[61,62]$. On the other hand, numerous epidemiological studies performed to date relate to a high intake of dietary fiber with low levels of GI and GL [63-65]. Moreover, DF has also shown to be effective improving altered parameters in obesity and T2DM [66,67]. Soluble viscous fiber plays an important role in controlling satiety and postprandial glycemic and insulin responses [68] and some studies showed that insoluble dietary fiber improved the quality of life for these patients [69]

The protective effect of DF on obesity and T2DM has been historically attributed to greater satiety due to an increased mastication, calorie displacement, and decreased absorption of macronutrients [55]. This mechanism is associated with the ability of soluble fibers to form viscous solutions that prolong gastric emptying, consequently inhibiting the transport of glucose, triglycerides and cholesterol across the intestine [70-72]. Recently, it was observed that both soluble and insoluble DFs also modifies carbohydrate metabolism by influencing the expression of hormones such as glucose-dependent insulin tropic polypeptide and glucagon-like peptide-1, that stimulate postprandial insulin release, enhance glucose tolerance, and delay gastric emptying [73-76].

\subsection{Fiber and gut microflora}

The large intestine plays host to a large and diverse resident microflora. Over the last 10-15 years, 16S ribosomal RNA analyses has allowed a more complete characterization of the diverse bacterial species that make up this population [77]. Around 95\% of human colonic microflora (as estimated from faecal sampling) appear to be within Bacteroides and Clostridium phylogenic groups, with less than $2 \%$ of the total microflora being made up of 
Lactobacilli and bifidobacteria [78]. In general, the colonic microflora is partitioned from the rest of the body by the mucus layer and mucosa. Loss of this partitioning effect is associated with disease processes within the large intestine [79], but it is unsure whether this is a cause or -effect of the disease process. Within the healthy large intestine, the main way the colonic microflora interacts with the host is through its metabolites [80]. Some of these metabolites are putatively damaging to the underlying mucosa, such as indoles, ammonia and amines while others are potentially beneficial to the host, including short chain fatty acids (SCFA) [81] and lignans that the mammalian gut can absorb $[82,83]$. SCFA are produced by bacterial fermentation of dietary carbohydrate sources, of which dietary fiber is the main type in the large intestinal lumen.

Dietary fiber, plays a profound role on the number and diversity of bacteria that inhabit the large intestine. In the absence of dietary fiber or other luminal energy sources, resident bacteria in the colon will turn to large intestinal mucus as an energy source prior to attacking the underlying mucosa [84]. As bacteria require the necessary enzymes to break down saccharide bonds of the diverse range of dietary fibers, fiber will clearly affect microfloral population dynamics. The presence of any fermentable dietary fiber is likely to lead to an increase in microfloral bifidobacterial and Lactobacillus levels, as these bacteria ferment carbohydrates. Previous studies in humans have suggested dietary fibers like alginate [85], chitosan [86], and inulin [87] lead to a reduction in potentially harmful microfloral metabolites. A range of small human interventions with various fermentable dietary fibers have shown significant, but small, clinical benefit in a number of intestinal diseases and disorders either on their own or in combination with probiotics [88-90].

Catabolism by microbial populations may also be important for decrease the levels of cholesterol and lipids. Bacteria such as Lactobacillus and Bifidobacteria can exert a hypocholesterolemic effect by enhancing bile acid deconjugation [91,92]. Furthermore, Lactobacillus and Bifidobacteria remove cholesterol in vitro by assimilation and precipitation $[93,94]$. Fermentation products further affect lipid metabolism. Propionate inhibits the incorporation of acetic acid into fats and sterols, resulting in decreased fatty acid and cholesterol synthesis [95].

\subsection{Fiber and Immune function}

Besides its absorptive functions, the gastrointestinal tract is involved with a range of immune functions. The mucosa effectively partitions the rest of the body from digestive enzymes, large numbers of bacteria and assorted toxins that occur within the gut. The mucosa has two main roles in immunity. Firstly, the mucosa samples luminal contents to assess the threat to the body because the gut comes into contact with a wide range of external antigenic compounds. This is carried out by the gut-associated lymphoid tissue or GALT [96]. In the second place, gut epithelium must also protect itself from the luminal stress of damaging agents and shear forces [97]. To do this, protective mucus is secreted along almost the entirety of the gastrointestinal tract (excluding the oesophagus and possibly Peyer's patches). Within the mouth, mucin is secreted alongside other salivary secretions and acts as a lubricant. In the stomach and intestine, mucus is secreted as a protective barrier [98]. 
There is a paucity of data regarding intake of DFs and immune function associated with the gut or otherwise in humans [99]. Animal studies within this area are also sparse. Field et al. [100] carried out studies with dogs and they found that fermentable fiber intake resulted in increased intra-epithelial T-cell mitogen response [92]. In a recent study it has been observed that DF may interact directly with immunoregulatory cells. Mucosal macrophages and dendritic cells have receptors with carbohydrate-binding domains that bind $\beta$-glucans and cause a decrease in IL-12 and increase in IL-10, which is consistent with an antiinflammatory phenotype [101]. No previous study has assessed the impact of DFs on the human mucus barrier due to the invasiveness of procedures involved with measuring the mucus barrier directly. However, the effects of different types of DFs on the intestinal mucus barrier have been studied in animal models. Fibers and fiber sources such as alginates, ispaghula husk, wheat bran, ulvan and carrageenan all appear to benefit the protective potential of the colonic mucus barrier [100,102].

\subsection{Fiber and prevention of cancer}

Cancer continues to be one of the number one health concerns of populations worldwide. Most cancers strike both men and women at about the same rate, with exception of cancers of the reproductive system. Of particular concern is cancer of the colon, ranking among the top 3 forms of cancer in the U.S.A., for both men and women. Colon cancer is also one of the leading causes of cancer morbidity and mortality among both men and women in the Western countries, including the U.S.A. [103]. The European Prospective Investigation of Cancer (EPIC) is a project that includes more than half a million people in 10 European countries and they results indicate that dietary fiber provides strong protective effects against colon and rectal cancer. In one of its papers, the authors clarify that methodological differences in some previous studies (e.g., study design, dietary assessment instruments, definition of fiber) may account for the lack of convincing evidence for the inverse association between fiber intake and colorectal cancer risk [104]. A careful work within the same project was conducted as a prospective case-control study nested within seven UK cohort studies which included 579 patients who developed incident colorectal cancer and 1996 matched control subjects. They used standardized dietary data obtained from 4- to 7day food diaries that were completed by all participants to calculate the odds ratios for colorectal, colon, and rectal cancers. In this work, the researchers confirmed that the intake of dietary fiber is inversely associated with colorectal cancer risk [105]. Taking into account these studies, the United States Food and Drug Administration has approved health claims in 2010 supporting the role of DF in the prevention of cancer [106].

Human metabolic and animal model studies indicate that beneficial effects of dietary fiber in relation to colon cancer development depend on the composition and physical properties of the fiber $[107,108]$. The effect of soluble fiber sources is mainly based on their fermentation and on the effects of short-chain fatty acids produced, especially of butyric acid. It has been known since 1982 that the colonic mucosa uses these acids, especially butyrate, as a preferential energy source [109]. Butyric acid stimulates the proliferation of normal cell lines both in vitro and in the normal epithelium, but retards the growth of 
carcinoma cell lines and induces apoptosis in cultured colonic adenoma and carcinoma cells $[110,111]$. Insoluble fiber has been found to have a protecting effect by absorbing hydrophobic carcinogens [112-114]. A third potentially effective mechanism is that of the accompanying phenolic compounds. Several phenolic compounds, having antioxidative properties, are present especially in cereal fiber sources. They are released from their bound states by bacterial enzymatic action in the colon, and can act in the intestine locally as anticarcinogens both in preventing cancer initiation and progression [115-117].

\section{Digestive and absorptive functions of the gastrointestinal tract and dietary fibers}

The gastrointestinal tract (GIT) is the initial site of action from which dietary fibers produce systemic effects presented in the previous section. The physiological effects of dietary fiber depend on a myriad of variables, but generally they depend on the type (soluble or insoluble), the dose of a specific fiber consumed, the composition of the entire fibercontaining meal, and the individual physiological profile of the subject who consume the fiber-containing meal [5]. The GIT serves as an interface between the body and the external environment. The main function of the GIT is to absorb nutrients from ingested foods. The organs of the GIT are connected to the vascular, lymphatic and nervous systems to facilitate regulation of the digestive function [118]. To carry out this function digestive processes are realized by secretion of enzymes and associated co-factors, and through maintenance of the gut lumen at optimal $\mathrm{pH}$ for digestion [119]. Gastrointestinal secretion of enzymes and other factors, alongside control of gut motility is governed by a series of complex neurohumoral pathways (mediated by acetylcholine, gastrin, motilin, cholecystokinin, gastric inhibitory peptide (GIP), secretin, etc.) that begin to operate by luminal content. Two main features of luminal content which appear to govern gastrointestinal physiology are luminal chemical profile and luminal bulk. The nutrient/chemical profile of the gut lumen is sensed by specialised chemosensor enteroendocrine cells within the epithelium [120], while mechanoreceptors (stretch activated neural cells) occurring within the myenteric and submucosal plexusues [121] are activated as a result of mechanical pressure from luminal contents. The main absorptive area in the gut is the small intestine, which is involved in the absorption of the subunits of digestible macronutrients, as well as vitamins, minerals and other micronutrients [87]. Ingested foods must be mechanically homogenised with digestive secretions in order to allow better hydrolysis of macronutrients, and, in some cases, to allow micronutrient release. Mastication in the buccal cavity mix food with salivary secretions among them $\alpha$-amylase starts digestion of starches [122]. Food boluses entering the stomach are maintained there for mixing with gastric secretions. A strongly acidic secretion allows denaturation of proteins and solubilisation of other factors. Gastric proteases (mainly pepsin) cleave bonds in proteins to form a range of shorter peptides and amino acids. Gastric lipase initiates digestion of dietary lipids [123]. By the time the majority of luminal contents leave the stomach, they have been processed into creamy, homogenous slurry, known as chyme. As luminal contents appear in the upper section of the small intestine (the duodenum), they are met with alkali (bicarbonate-rich) secretions from the liver, pancreas 
and intestinal crypts. Pancreatic exocrine secretions also contain a myriad of enzymes for digestion of all macronutrients [124].

Classically, dietary fiber is cited as reducing whole gut transit time, thereby increasing frequency of defecation. This effect can be explained on the one hand, due to DF increase the intestinal luminal bulk resulting in an increased peristalsis which reduce the whole gut transit time. DFs that increment the luminal bulk are those that have a high water-binding capacity [125]. Furthermore, feed-forward and feedback from other portions of the gut as a result of fiber intake could also affect motility of the different organs of the GIT. Prolongation of nutrient release into the intestinal lumen from the stomach is likely to result in a lengthened phase of hormonal feedback from the duodenum, terminal ileum and colon, leading to a delay in gastric emptying [84]. At the same time, this delay in the gastric emptying towards small intestine are likely to increased motility distally (and therefore decreased transit time). The most researched area of the effects of dietary fibers on gastric motility is linked to gastric emptying. A range of studies have demonstrated that inclusion of viscous fibers in liquid test meals results in delayed gastric emptying, and are particularly consistent in the case of pectins in human studies [126,127]. In a study comparing the physiological effects of a mixed meal containing high levels of natural fibers (fruit, vegetables and whole grains) against one without these fibers (instead containing fruit and vegetable juice and refined grains), concluded that removal of natural fiber decreased gastric emptying mean rate of approximately $45 \mathrm{~min}$ in a crossover feeding trial in 8 healthy adult participants [128]. The dietary fibers that raise the bulk of luminal contents of the large bowel are those that are not well fermented by the colonic microflora, and those that have a high water-binding capacity [84].

\subsection{Nutrients absorption}

To date, evidence has been obtained in different types of studies that dietary fiber can influence the metabolism of carbohydrates and lipids preventing the development of diabetes mellitus and cardiovascular disease. Intake of dietary fiber can influence the absorption of nutrients in different ways. It has been postulated that the presence of any dietary fiber in the upper GI tract will result in a decreased rate of intestinal uptake of a range of nutrients. However, it is necessary to consider what physicochemical factors of dietary fibers are important in these roles [84]. In previous animal studies, Kimura et al. [129], noted higher levels of cholesterol excretion in rats fed diets containing $1000 \mathrm{mg} / \mathrm{kg}$ of degraded alginates with molecular weights of 5 and $10 \mathrm{KDa}$ compared to the effect of a diet with a lower molecular weight $(1 \mathrm{kDa})$ alginate or a control (no fiber) diet. While such absorption-lowering effects can be beneficial in reducing energy uptake, it must also be noted that such factors are also likely to reduce the bioavailability of minerals, vitamins and phyto-chemicals. Dietary fiber fractions differ largely in their abilities to affect mineral and trace element availability and this might have negative impacts in high-risk population groups. Small human feeding studies have suggested that inclusion of food hydrocolloids like alginates [130], guar gum [131,132] and $\beta$-glucan [58,133-135] into test meals results in a blunting of postprandial glycaemic and insulinaemic responses. 


\section{In vitro chemical experimental models}

To study the absorption of nutrients in vivo, feeding methods, using animals or humans, usually provide the most accurate results, but they are time consuming and costly, which is why much effort has been devoted to the development of in vitro procedures [136]. The in vitro digestive chemical experimental model enabled mimicking, in the laboratory, the in vivo reactions that take place in the stomach and duodenum. In principle, in vitro digestion models provide a useful alternative to animal and human models by rapidly screening food ingredients. The ideal in vitro digestion method would provide accurate results in a short time [137] and could thus serve as a tool for rapid food screening or delivery systems with different compositions and structures [19]. In vitro methods cannot be used alone for important decisions taken by industry or international organizations because human studies are required for such determinations, but are important for screening purposes and to project future studies.

\section{Work objective}

Considering the fact that dietary fibers are new ingredients widely applied in foods, it is important to know their effect on absorption of nutrients and micronutrients. For this reason, the interaction between nutrients and fibers from different sources (animal and plant fibers) and types (soluble and insoluble fibers) has been studied using chemical experimental models of the human digestive tract to evaluate the availability for absorption of glucose, calcium and iron using yoghurt as a food model.

\section{Materials and methods}

\subsection{Dietary fibers employed}

The plant fibers used in this work were: inulin (Frutafit-inulin, Imperial Sensus, The Netherlands), bamboo (Qualicel, CFF, Gehren, Germany), wheat (Vitacel WF 101, JRS, Rosenberg, Germany), apple (Vitacel AF 400-30, JRS, Rosenberg, Germany) and psyllium (Metamucil, Procter and Gamble Co., Cincinnati, OH, USA). Metamucil is a pharmaceutical formula with Plantago ovata seed husk $(49.15 \% \mathrm{w} / \mathrm{w})$ and sucrose $(50.85 \%)$. Suppliers of wheat and apple fiber indicated that these products are free from phytic acid, and besides, the wheat fiber is gluten free. The inulin utilized in this work has a degree of polymerisation $\geq 9$ as declared by suppliers.

The dietary fiber from animal source utilised in these assays was chitosan. It was obtained from crustacean chitin in the Laboratorio de Investigación Básica y Aplicada en Quitina (LIBAQ-INQUISUR-CONICET), Universidad Nacional del Sur, Bahía Blanca, Argentina. Chitin firstly was isolated from shrimp (Pleoticus mülleri) waste by the process that was described in our previous work [138]. Chitosan was prepared directly by heterogeneous deacetylation of chitin with $50 \%(\mathrm{w} / \mathrm{w}) \mathrm{NaOH}$. For the biopolymer characterisation, moisture and ash contents were determined at $100-105{ }^{\circ} \mathrm{C}$ and $500-505{ }^{\circ} \mathrm{C}$, respectively. 
Deacetylation degree was obtained using FT-IR spectroscopy (Nicolet iS10 FT-IR Spectrometer, Thermo Fisher Scientific, USA) with samples in the form of $\mathrm{KBr}$ at a ratio of 1:2. Viscosity of $1 \%$ chitosan in $1 \%$ acetic acid solution was measured with a Brookfield model DV-IV + viscosimeter (Brookfield, USA) with spindle 21 and a $50 \mathrm{rpm}$ rotational speed at $25^{\circ} \mathrm{C}$ [139].

\subsection{Analysis for dietary fiber}

Total, soluble and insoluble dietary fiber contents of chitosan and plant fibers were analysed according to the enzymatic-gravimetric method of the Association of Official Analytical Chemists (AOAC) Official Method 991. 43 [140]. Apple, bamboo, psyllium and wheat fibers were investigated to obtain contents of main cell wall constituents (lignin, cellulose, hemicellulose). These components were determined by modifications of the method described by Robertson and van Soest [38, 141] using ANKOM200/220 Fiber Analyzer (ANKOM Technology, Macedon, NY, USA). This method measures Acid Detergent Fiber (ADF), Neutral Detergent Fiber (NDF) and Lignin. Cellulose and hemicellulose contents were obtained by calculations. To determine ADF, duplicate samples were agitated under pressure with hot acid detergent solution for $60 \mathrm{~min}$, rinsed in hot water and dried. To determine lignin content, duplicated samples were digested in $72 \%(\mathrm{v} / \mathrm{v})$ sulfuric acid, following ADF analysis. Cellulose content of samples was calculated from ADF minus the lignin content. To determine NDF, duplicated samples were shaken with neutral detergent solution and heat-stable $\alpha$-amylase for $60 \mathrm{~min}$, rinsed and dried. Hemicellulose content of samples was calculated as NDF minus ADF [141].

\subsection{Yoghurt preparation}

Yoghurt was prepared using reconstituted whole milk powder $(15 \% \mathrm{w} / \mathrm{w})$ and $5 \%$ sucrose. This mix was homogenized and heated to $85{ }^{\circ} \mathrm{C}$ for $30 \mathrm{~min}$., cooled to ambient temperature and inoculated with $0.03 \%$ starter culture. Starter was constituted by a 1:1 mixture of Streptococcus thermophilus (CIDCA collection 321) and Lactobacillus delbrueckii subsp. bulgaricus (CIDCA collection 332). Samples were incubated at $43^{\circ} \mathrm{C}$ to reach a $\mathrm{pH}$ of $4.4-4.6$ and stored at $4^{\circ} \mathrm{C}$, after completion of the fermentation process $1.3 \%(\mathrm{w} / \mathrm{w})$ of each dietary fiber was added to samples of yoghurt [142]. The amount of fiber was selected following US regulations for fiber-fortified products [143].

To study glucose availability 0.6 g of glucose (Sigma-Aldrich Co., St. Louis, MO, USA) was added for each sample of yoghurt with each type of dietary fiber. In calcium availability studies the digestive mimicking was done without the addition of exogenous calcium because yoghurt is a source of calcium in the diet [138]. To evaluate the interactions between the fibers and iron, $0.8 \%(\mathrm{w} / \mathrm{w})$ of ferrous sulfate was added to yoghurt samples with each type of fiber [139]. This addition was in accordance with local regulations governing iron supplementation in milk products. Ferrous sulfate $\left(\mathrm{FeSO}_{4} \cdot 7 \mathrm{H}_{2} \mathrm{O}\right)$ of $99.9 \%$ purity was used as purchased (Sigma-Aldrich Co., St. Louis, MO, USA). 


\subsection{Digestive chemical experimental model}

Two types of digestive simulations were performed to study the interactions between dietary fibers used and the macro and micro nutrients tested. To evaluate the interaction of glucose and calcium with the fibers, gastric and duodenal environments were simulated. To examine the interactions between the fibers and iron was used in addition, a dialysis membrane to imitate the iron passage through the intestinal wall. Digestive enzymes were not utilized in these models because they do not hydrolyze fibers. The importance of duodenal simulation in these studies is because most dietary glucose, calcium and iron are absorbed in the duodenum.

The experiments to study the availability of glucose and calcium were performed in the following steps: a mix of $12.5 \mathrm{~g}$ of yogurt with $0.3 \mathrm{~g}$ of each fiber was stirrer in $50 \mathrm{~mL}$ of $0.1 \mathrm{M}$ $\mathrm{HCl}$ (Merck) $\mathrm{pH} 1.0-2.0,30 \mathrm{rpm}$ and $37^{\circ} \mathrm{C}$ to reproduce the gastric environment. After 1 hour simulations were taken from the acidic medium to $\mathrm{pH}$ 6.8-7.2 with $15 \mathrm{~g} / \mathrm{L}$ of $\mathrm{NaHCO}_{3}$ (Sigma Chemical Co., St. Louis, MO, USA). The stirring speed was increased from 30 to $300 \mathrm{rpm}$ and the temperature was maintained at $37^{\circ} \mathrm{C}$ to reproduce the duodenal environment. Then simulations were allowed to rest for 15 min until two phases separated. Samples to determine glucose and calcium concentration were taken from the supernatant. Glucose and calcium amounts, determined by this way, represent the bioavailability fraction of those nutrients. A control without fibers was made to consider glucose and calcium $100 \%$ availability [138].

Experiments to study the interaction of dietary fibers with iron were carried out in the following manner. Yoghurts with ferrous sulfate and each fiber were stirred in $50 \mathrm{~mL}$ of $0.1 \mathrm{M}$ $\mathrm{HCl}$ (Merck) for $1 \mathrm{~h}$ at $\mathrm{pH} 1.0-2.0,30 \mathrm{rpm}$ and $37{ }^{\circ} \mathrm{C}$ to reproduce the gastric environment. During this first step of simulation $\mathrm{pH}$ was checked each 15 min with a $\mathrm{pH}$ Meter Hach model EC-30 (USA) and it remained constant ( $\mathrm{pH}$ 1.0-2.0). To reproduce the chemical duodenal environment $\mathrm{pH}$ level was increased to $\mathrm{pH}$ 6.8-7.2 with 0.2 M NaHCO3 (Sigma-Aldrich Co., St. Louis, MO, USA), stirring speed was increased from 30 to $300 \mathrm{rpm}$ to imitate the peristaltic movement and temperature was maintained at $37^{\circ} \mathrm{C}$. Simulations were immediately transferred into a dialysis tubing cellulose membrane (D9527-100 FT, (Sigma-Aldrich Co., St. Louis, MO, USA). This cellulose membrane (molecular weight cut-off 12,400) was previously prepared, as indicated by suppliers, and it was cut into $28 \mathrm{~cm}$ length pieces. The loaded tubes were immersed in $100 \mathrm{~mL}$ of distilled water; at $37^{\circ} \mathrm{C}$. Iron concentrations were determined from the dialysed medium at 30 and 60 minutes. Control yoghurt with ferrous sulfate without fibers was subjected to the digestive simulation and was considered as $0 \%$ iron retention to calculate iron retention percentages for each fiber [139].

\subsection{Analytical techniques}

To determine glucose concentration an enzymatic method was used. Glucose reacts with 10 $\mathrm{kU} / \mathrm{L}$ glucose oxidase (GOD), and $1 \mathrm{kU} / \mathrm{L}$ peroxidase (POD) in presence of $0.5 \mathrm{mM} 4$ aminophenazone (4-AP) and $100 \mathrm{mM}$ phosphate buffer ( $\mathrm{pH}$ 7.0) containing $12 \mathrm{mM}$ hydroxybenzoate (Wiener Lab Glicemia enzymatic AA Kit, Argentina). An amount of 
digestive simulation solution $(10 \mathrm{~mL})$ was mixed with $1.0 \mathrm{~mL}$ of reagent, tubes were incubated for $5 \mathrm{~min}$ in water bath at $37^{\circ} \mathrm{C}$ and developed colour were read in spectrophotometer (Spectronic 20 Genesys TM, Spectronic Instrument, USA) at $505 \mathrm{~nm}$. Final reaction colour is stable for $30 \mathrm{~min}$. Glucose calibration curve was carried out. The amounts of glucose used in this study correspond to available carbohydrates in the human mixed diet.

To determine calcium concentration a spectrophotometric method was used. Calcium reacts with $3.7 \mathrm{mmol} / \mathrm{L}$ cresolphtalein complexone (Cpx) at $\mathrm{pH} 11$ (buffer $0.2 \mathrm{~mol} / \mathrm{L}$ aminomethylpropanol (AMP) solution in 35\%v/v methanol) (Wiener Lab Ca-color Kit, Argentina). Assays were carried directly in spectrophotometer test tubes: $50 \mathrm{lL}$ Cpx were mixed with a plastic rod and absorbance was read in spectrophotometer (Spectronic 20 Genesys TM, Spectronic Instrument, USA) at $570 \mathrm{~nm}$ (internal blank), then $20 \mathrm{~mL}$ of each digestive mimicking sample were added, immediately mixed and read after $10 \mathrm{~min}$. A standard curve was developed [138].

To determine iron concentration in the dialysates a spectrophotometric method was used, $500 \mu \mathrm{L}$ of dialyzates was reduced with $2 \mathrm{~mL}$ of mercaptoacetic acid (succinic acid buffer, $\mathrm{pH}$ 3.7). Then, iron reacted with one drop of pyridyl bis-phenil triazine sulfonate (PBTS) producing a pink color due to the complex formed (Wiener Lab Fe-colour Kit, Rosario, Argentina). Absorbance was read on a spectrophotometer (Spectronic 20 Genesys Thermo Electron Scientific Instruments Corp., Madison, WI, USA) at $560 \mathrm{~nm}$ (internal blank). All glassware used in sample preparation and analysis was rinsed with $10 \%(\mathrm{v} / \mathrm{v})$ concentrated $\mathrm{HCl}(37 \%)$ and deionised water before using, to avoid mineral contamination. A regression equation $(\mathrm{y}=2.5333 \mathrm{x}+0.0042, \mathrm{R} 2=0.995)$ derived from data generated from standards of $\mathrm{FeSO}_{4}$ was used to calculate iron concentrations in the samples. Iron retention percentages for each studied fibers were calculated as a percentage of the amount of iron measured in the dialysed medium obtained with the control yoghurt without fibers [139].

\subsection{Statistical analysis}

Experiments were performed at least five times for each dietary fiber using freshly prepared yogurt. For total iron concentration in dialyzates, each individual sample was run in duplicate. Averages and standard deviations were calculated and expressed in each case as the mean \pm SD for $n$ replicates. Normality of the data was checked with the Lilliefors test. The influence of different dietary fibers on the retention percentages of glucose, calcium and iron were statistically analyzed by a one-way analysis of variance (ANOVA) $(p<0.05)$ to find significant differences and Tukey's test to compare means.

\section{Results and discussion}

\subsection{Characterisation of fibers}

The dietary fibers used in this study have different water solubility characteristics: inulin is a soluble fiber, bamboo and wheat are insoluble fibers, apple is partially insoluble fiber, and psyllium forms a viscous dispersion at concentrations below $1 \%$ and a clear gelatinous mass 
at $2 \%$. Chitosan is a fiber of a different origin, i.e. from animal source and is soluble in an acidic medium and flocculates in an alkaline medium. We used these fibers because they present different physicochemical behaviors that have been described in literature [144,4]. The commercial fiber compositions used in this study, regarding total, soluble and insoluble fractions, are shown in Table 4. Analysis for dietary fiber using the AOAC method 991.43 showed that wheat and bamboo have high amounts of insoluble fraction.

\begin{tabular}{cccccc}
\hline Fiber & $\begin{array}{c}\text { Insoluble } \\
\text { fiber }\end{array}$ & $\begin{array}{c}\text { \% Insoluble } \\
\text { fiber }\end{array}$ & $\begin{array}{c}\text { Soluble } \\
\text { fiber }\end{array}$ & $\begin{array}{c}\text { \% Soluble } \\
\text { fiber }\end{array}$ & $\begin{array}{c}\text { Total } \\
\text { fiber }\end{array}$ \\
\hline Apple & $44.8 \pm 0.4$ & 77.1 & $13.3 \pm 0.7$ & 22.9 & $58.1 \pm 1.0$ \\
Bamboo & $91.4 \pm 0.5$ & 95.9 & $3.2 \pm 0.8$ & 3.4 & $95.3 \pm 0.9$ \\
Chitosan & $98.0 \pm 1.0$ & 100 & nd & nd & $98.0 \pm 1.0$ \\
Inulin & nd & Nd & $\geq 85.5$ & 100 & $\geq 85.5$ \\
Psyllium & $37.5 \pm 0.6$ & 82.9 & $7.1 \pm 0.5$ & 15.7 & $45.2 \pm 0.8$ \\
Wheat & $92.1 \pm 0.6$ & 97.6 & $2.3 \pm 0.6$ & 2.4 & $94.4 \pm 1.1$ \\
\hline
\end{tabular}

nd: no detectable

Table 4. Total, soluble and insoluble fiber content $(\mathrm{g} / 100 \mathrm{~g})$ of employed fibers

Inulin presents only soluble fraction as expected. Psyllium and apple have both soluble and insoluble fractions. Apple fiber is characterized by a well balanced proportion between soluble and insoluble fraction [145]. The total dietary fiber content is $45.2 \%$ for psyllium, which is an acceptable value, taking into account that the supplier declared a $49.15 \%$ content for Plantago ovata seed husk in Metamucil preparation. Van Craeyveld et al. [146] reported $3.4 \%(\mathrm{dm})$ ash and $7.1 \%(\mathrm{dm})$ protein contents for Plantago ovata seed husks. The total dietary fiber content is $58.1 \%$ for apple, which is about $10-14 \%$ higher than the values reported by Sudha et al. [147]; however, this value was in accordance with suppliers. The chitosan used in this study has $98 \%$ of insoluble fraction and no detectable soluble fraction. Furthermore the characteristics of this biopolymer are a deacetylation degree of $89 \%$, a viscosity of $120 \mathrm{mPa} . \mathrm{s}, 6.7 \mathrm{~g} \%$ moisture and $0.67 \mathrm{~g} \%$ ash content.

Plant fiber characterisations were completed with the study of Acid Detergent Fiber (ADF) and Neutral Detergent Fiber (NDF), lignin, cellulose and hemicellulose contents (Table 5). Apple presents the highest lignin content. Wheat fiber mainly has cellulose. Bamboo has proportional amounts of cellulose and hemicellulose, but compared with other fibers, has the highest hemicellulose content. These results are in accordance with their plant fiber origins and previous works [145-149]. Frutafit-Inulin was not analysed because its composition was $\geq 85.5 \%(\mathrm{w} / \mathrm{w})$ of inulin, $\leq 9.5 \%$ of mono and disaccharides, $\leq 0.1 \%$ of ash with polymerisation degree $\geq 9$ according to suppliers. Chitosan was not analysed either, because of its animal origin. 


\begin{tabular}{cccccc}
\hline Fibre & ADF & NDF & Lignin & Cellulose & Hemicellulose \\
\hline Apple & $38.6 \pm 0.9$ & $44.3 \pm 0.7$ & $8.4 \pm 0.8$ & $30.2 \pm 1.7$ & $5.7 \pm 1.6$ \\
Bamboo & $50.2 \pm 0.7$ & $90.4 \pm 0.6$ & $5.0 \pm 0.3$ & $45.2 \pm 1.0$ & $40.2 \pm 1.7$ \\
Psyllium & $7.3 \pm 0.4$ & $36.8 \pm 0.9$ & $0.8 \pm 0.1$ & $6.5 \pm 0.4$ & $29.5 \pm 1.3$ \\
Wheat & $74.8 \pm 0.3$ & $89.7 \pm 0.6$ & $2.6 \pm 0.4$ & $72.2 \pm 0.7$ & $14.9 \pm 0.9$ \\
\hline
\end{tabular}

Table 5. Acid Detergent Fiber (ADF), Neutral Detergent Fiber (NDF), lignin, cellulose and hemicellulose $(\%)$ of fibers

Scientists who deal with animal nutrition usually use Van Soest's method to analyse feed. Scientists working on human nutrition use methods of the AOAC, because of their interest in soluble fiber. It is known that soluble fiber plays an important role in human health and the food industry. However, it could be useful in human nutrition to know the composition of insoluble fiber, as it is possible that insoluble fibers do not all have the same effect on human health. The NDF and insoluble fiber methods were applied to the same samples. Insoluble fiber includes hemicellulose, cellulose, lignin, cutin, suberin, chitin, chitosan, waxes and resistant starch. NDF includes hemicellulose, cellulose and lignin. Escarnot et al. [149] studied three wheat varieties and four spelt genotypes. They analysed three milling fractions from those grains for insoluble and soluble fiber contents, lignin, hemicellulose and cellulose. They found a very high correlation $\left(\mathrm{r}^{2}=0.99\right)$ between the two methods, showing that NDF and insoluble fiber methods cover the same types of fiber. For insoluble fiber analysis, the NDF method is faster and more thorough.

\subsection{Digestive chemical model and glucose, calcium and iron retention percentages}

Dietary fiber have been found to have the capacity of binding different substances like bile salts and glucose which have implications in cholesterol lipid and carbohydrate metabolism respectively, as presented in the preceding sections. However, the continuous introduction of new ingredients in the food industry requires further studies in order expand knowledge of the impact on nutrient absorption.

Figure 1 shows the behavior of samples during the digestive tract simulation to evaluate glucose and calcium retention percentages and macroscopical differences between them could be observed. Different simulated digestive contents for different fibers before dialysis in assays to determine the iron retention percentages are not shown because they are similar to those presented in Fig. 1. Simulation of gastrointestinal environment during dialysis of different yoghurts can be observed in Figure 2. Changes in $\mathrm{pH}$ during gastrointestinal simulation produces different behaviors depending on the type of fiber employed. The apple fiber is a fine powder with brownish color, probably due to the content of phenolics compounds [150]. When apple fiber is added to the yogurt and subjected to the gastrointestinal simulation this color persists (Figure 1). In Figure 2 it can be seen that Psyllium fiber gives a viscous dispersion [151,152]. Due to changing $\mathrm{pH}$ values in the 


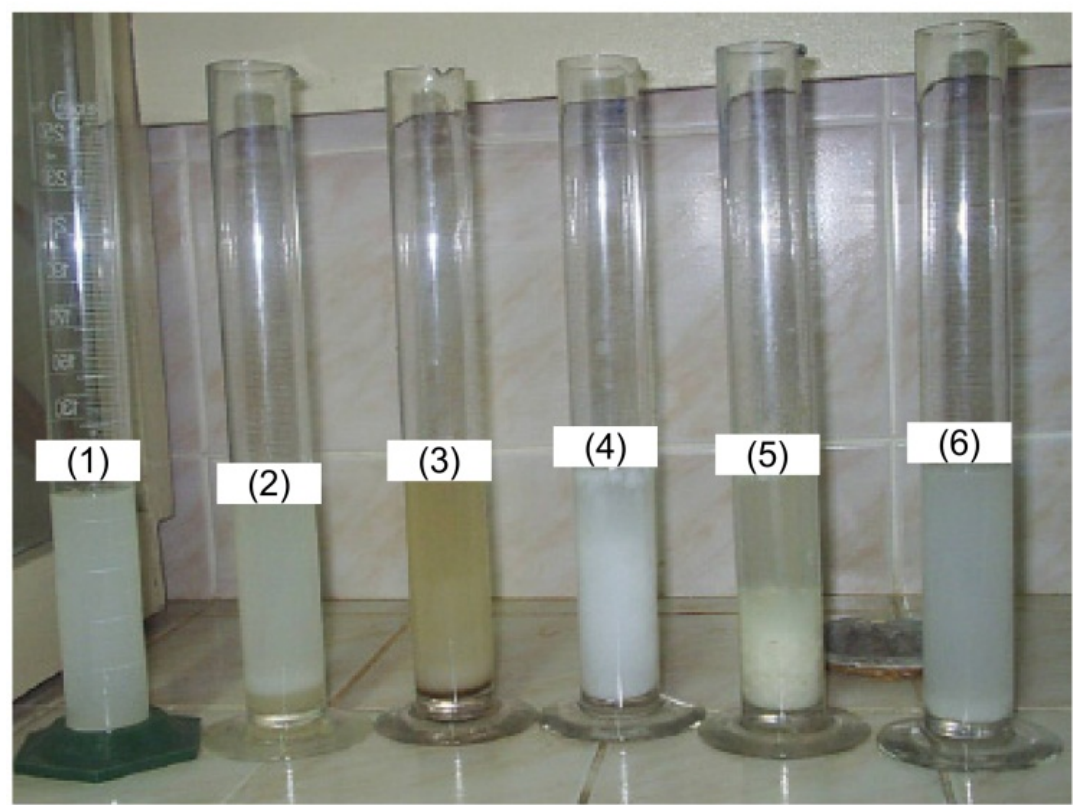

(1) Wheat, (2) psyllium, (3) apple, (4) inulin, (5) chitosan and (6) bamboo fibers.

Figure 1. Photograph of the macroscopic view of different fibers in the in vitro digestive tract simulation.

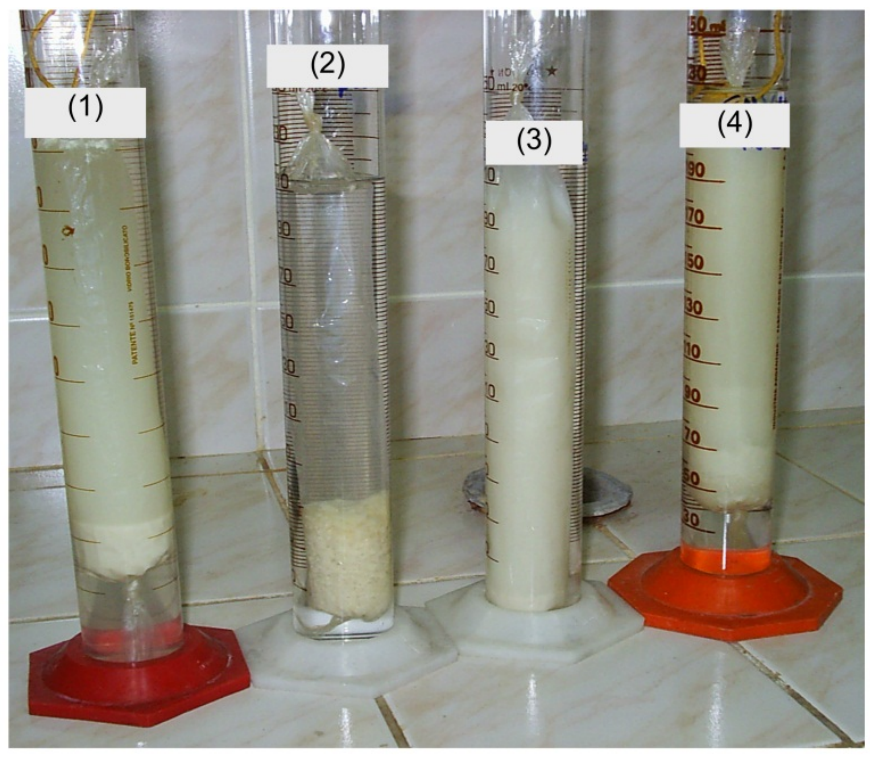

(1) Yoghurt without fiber, (2) chitosan, (3) psyllium, (4) wheat.

Figure 2. Different fiber behaviors in the dialysis step of digestive simulation. 
digestive tract, Chitosan precipitates while passing through the first portion of the small intestine, forming flocculus. Chitosan, that is a positively charged polysaccharide, is insoluble in neutral and alkaline $\mathrm{pH}$. It is only soluble in acidic $\mathrm{pH}$ because below $\mathrm{pH} 6.5$ $(\mathrm{pKa}=6.5)$, the amine groups of chitosan are positively charged. When it is solubilised in dilute acid, chitosan has a linear structure [153]. At $\mathrm{pH}>6.5$, the polymer loses its charges from the amine groups and therefore becomes insoluble in water and precipitate forming flocculus.

Using the model that reproduces in vitro gastrointestinal conditions we determined glucose availability reduction and the results are shown in Figure 3. Significant differences $(p<0.05)$ are observed in glucose availability reduction percentage for the different fiber samples. In the gastrointestinal conditions chitosan formed a flocculus that entrapped glucose so its availability reduction is the highest. Psyllium increases viscosity medium and glucose availability reduction is $15.3 \pm 1.8 \%$; wheat has $9.5 \pm 2.1 \%$ of glucose retention and inulin 5.7 $\pm 1.8 \%$, apple and bamboo showed no availability reduction. This in vitro study supports the view that certain types of dietary fiber reduce the rate of glucose absorption but chitosan has the most pronounced effect. The behavior in delaying absorption could be likely to alter the gut endocrine response both by carrying material further down the small intestine prior to absorption as well as by producing a flatter blood glucose profile.

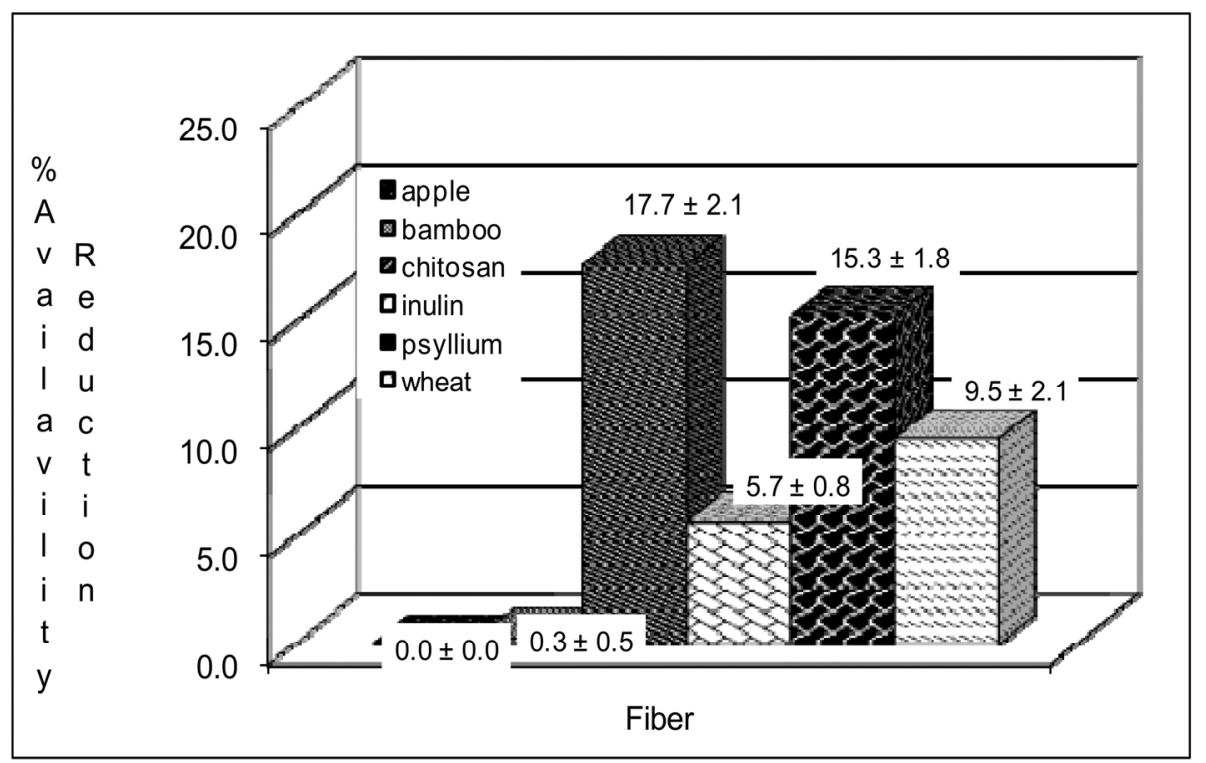

Figure 3. Glucose availability reduction

On the other hand, dietary fiber may influence the availability of minerals, such as calcium, magnesium [154] and iron [155]. Animal studies have found that dietary chitosan possibly arrests the absorption of calcium [156,157]. 
To study calcium availability the same model for glucose was used but without the addition of exogenous calcium because yogurt is an important source of this mineral in the human diet. Data are shown in Figure 4. Statistical analysis confirmed significant differences $(\mathrm{p}<$ 0.05 ) among the behavior of the different fibers with calcium. It is observed $16.5 \pm 1.6 \%$ of calcium availability reduction for apple fiber that have significant differences with the others fibers. However availability reduction responses, between insoluble fibers (wheat and bamboo) and soluble ones (inulin and psyllium plantago), have no significant differences $(p<0.05)$ by Tukey's test. Again, like results obtained with glucose, this study demonstrated that the chitosan effect is more pronounced and higher than for the other studies [138].

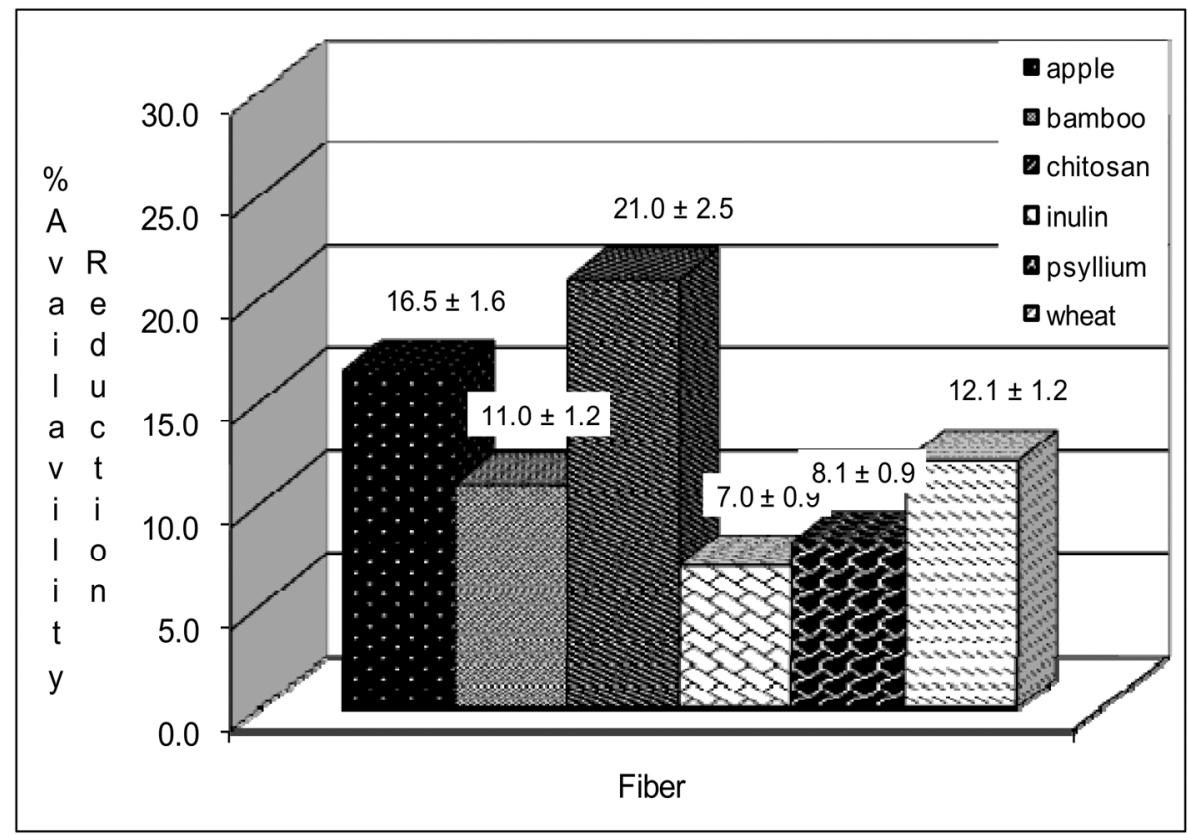

Figure 4. Calcium availability reduction.

To study iron retention percentages by the fibers tested in the present study, the introduction of cellulose dialysis tubes in the digestive chemical experimental model is utilised. The use of a membrane dialysis tube reproduces, in the laboratory, the duodenum wall and its utilisation is presumably a significant factor that determines iron absorption according to Miret et al. [158].

In yoghurt, caseins are modified as a consequence of its production process. Bioactive peptides are formed from caseins during the elaboration of milk products (cheese, yoghurt) under the action of endogenous enzymes of milk (plasmin, cathepsin, among others) or of microorganisms [159]. These peptidic fragments that are already present in yoghurt, could fix iron and calcium according to Bouhallab and Bouglé [159]. Then, these complex matrices 
(yoghurts with each type of fiber and iron or calcium) are subjected to the gastrointestinal simulation. Control yoghurt with ferrous sulfate without fiber was also subjected to the digestive simulation and considered to be $0 \%$ iron retention $(100 \%$ iron dialyzated) to calculate iron retention percentages for each fiber. Similarly, control yoghurt without fibers was subjected to the digestive simulation to estimate calcium $100 \%$ availability. With these control yoghurts, we could consider the interaction of iron or calcium with casein peptidic fragments.

Iron retention percentages of different fibers are presented in Figure 5. Bamboo and wheat fibers, both insoluble, have low iron retention percentages between $2-5 \%$ at 30 min with a maximum of $10 \%$ at $60 \mathrm{~min}$. There are no significant differences $(\mathrm{p}<0.05)$ between them by Tukey's test. Bamboo and wheat are high in cellulose content. Cellulose could retain iron by physical adsorption according to results reported by Torre et al. [15]. They worked with high dietary fiber food materials studying the physicochemical interactions with $\mathrm{Fe}(\mathrm{II})$, $\mathrm{Fe}(\mathrm{III})$ and $\mathrm{Ca}(\mathrm{II})$ without an in vitro digestive model. They found that the interaction between Fe(II) and cellulose could be explained better by physical adsorption than complex formation. Inulin, a soluble fiber, has no iron retention at 30 or $60 \mathrm{~min}$ of simulation. This result is in accordance with studies that confirm that inulin does not interfere with iron absorption [17,20,160,161].

Although psyllium and apple fiber contain both soluble and insoluble fractions, they have significantly different responses $(p<0.05)$. The apple fiber incorporated in yoghurt has no

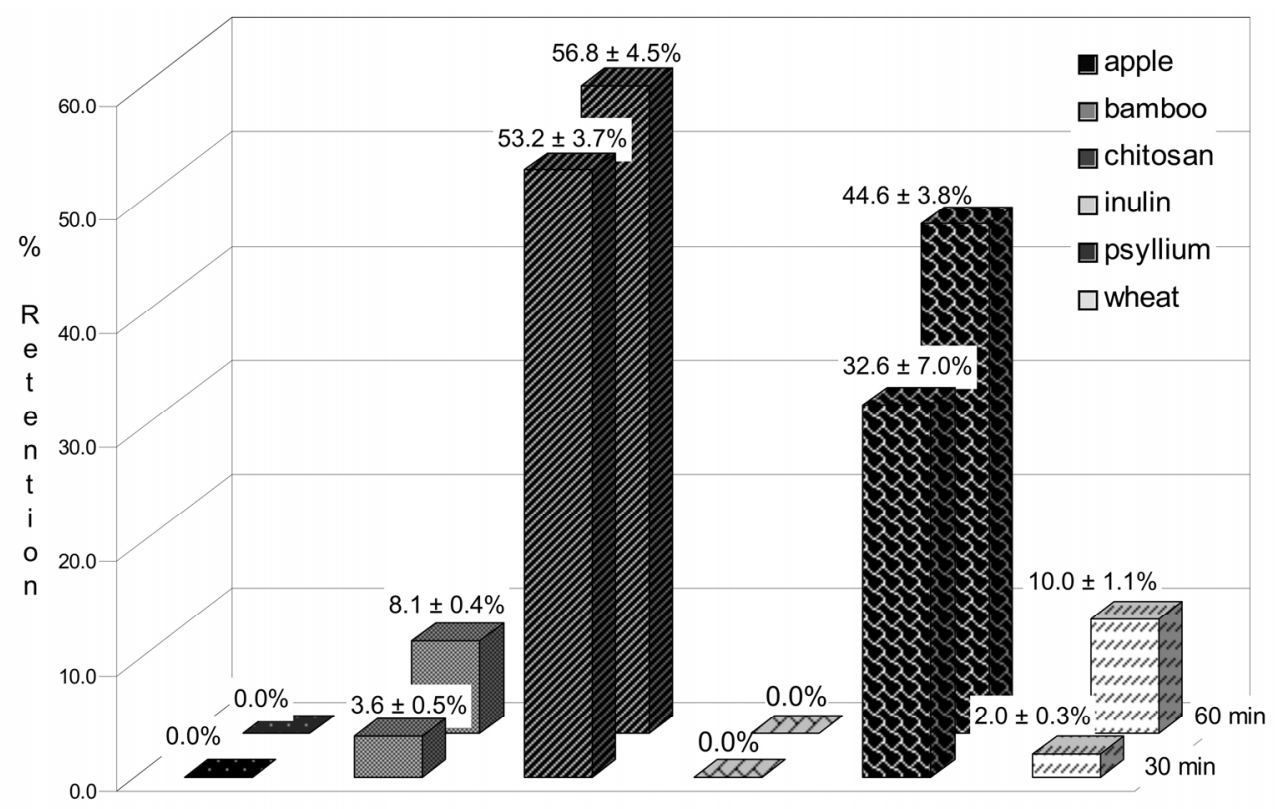

Figure 5. Iron retention percentages of yoghurts with different studied fibers 
influence on iron retention. Psyllium shows, on average, $44.6 \pm 3.8 \%$ iron retention at $60 \mathrm{~min}$, which may be mainly attributed to the formation of high viscous dispersion that could be interfering with iron absorption (Figure 2). In addition, the differing behaviors between apple fiber and psyllium could be explained by the different chemical composition of these fibers. Psyllium has high hemicellulose content and apple has the highest lignin content and cellulose. However, bamboo has a low iron retention percentage. The bamboo behavior could be explained due to the composition with equal proportions of soluble and insoluble fractions. More research is needed of this type of fiber.

Chitosan presents the highest iron retention percentages at $30 \mathrm{~min}(53.2 \pm 3.7 \%)$ and $60 \mathrm{~min}$ $(56.8 \pm 4.5 \%)$, which shows significant differences $(\mathrm{p}<0.05)$ with other fibers. This biopolymer, which has an animal origin, contains $98 \%$ insoluble fiber, and flocculates in the first portion of the small intestine. This flocculus (Figure 2), which could entrap iron, clearly decrease iron dialysis. However, certain amount of iron could go through the cellulose membrane and could be measured to calculate the iron retention percentage. Certain amount of casein-peptide-fragments interacting with iron could remain in solution. Nevertheless, their presence does not interfere with the calculation of iron retention percentages as proven by the digestive simulations performed with control yoghurts.

This study shows that the effect of chitosan on iron absorption is more pronounced and higher than those measured for the other studied plant fibers, as dietary fiber is a significant factor that influences iron absorption. The iron retention percentages of different fibers used in this work could be explained mainly as a result of physicochemical phenomena, like adsorption, formation of viscous dispersion and flocculus.

Yoghurt contains peptidic fragment $s$ from caseins. The caseins are amphiphilic phosphoproteins and their isoelectric point $(\mathrm{p} I)$ value is 4.6 . At $\mathrm{pH}$ above the $p I$, caseins are negatively charged and soluble in water. The caseins have an electronegative domain preferentially located in small peptidic fragments known as $\alpha$ s1-Casein, $\beta$-casein and $\kappa$ casein. These structural features of the caseins may render these molecules adept at forming complexes with multivalent cationic macromolecules, such as chitosan [153]. In yoghurt ( $\mathrm{pH}$ $=4.4-4.6$ ) aggregation of the casein-peptide-fragments occur because of a reduction in the electrostatic repulsion at around their $p I$ value. Anal et al. [153] studied the interactions between sodium caseinate and chitosan, under a range of conditions. This study showed that soluble or insoluble chitosan-caseinate complexes can be formed depending on the $\mathrm{pH}$. The characteristics of the complexes are determined by the biopolymer types and their concentration, as well as by environmental conditions. In a certain $\mathrm{pH}$ range (5.0-6.0), nanocomplexes of chitosan and sodium caseinate with diameter between 250 and $350 \mathrm{~nm}$ were formed. The chitosan and sodium caseinate complexes associated to form larger particles, which resulted in phase separation appear when the $\mathrm{pH}$ was either in the range 4.0-4.5 or $>6.5$. At $\mathrm{pH} 3.0-3.8$, where chitosan and sodium caseinate have similar charges, they may dissociate from each other and become solubilized in solution. According to these authors, yoghurts with chitosan could contain chitosan-casein-peptidic complexes apart from free chitosan molecules in solution. 
Besides, calcium existing in yoghurt or the added iron could interact with free chitosan molecules and those complexes. In our work, yoghurts with chitosan are subjected to gastrointestinal simulations. In the first step, our food passes through the simulated stomach $(\mathrm{pH}=1.0-2.0)$ and it could be expected that casein peptidic fragments, chitosan, iron or calcium, all remain in solution. While the food passes through the first portion of the simulated small intestine, changes in $\mathrm{pH}$ can lead to formation of chitosan-casein peptidic complexes and iron or calcium could be interacting with them. At pH 6.8-7.0, free chitosan molecules and chitosan-casein-peptidic complexes precipitate forming flocculus. The force of the coagulum formed is high and can be seen in Figures 1 and 2. The results reported by Ausar et al. [162] indicate that hydrophobicity of the casein-chitosan complex is the main mechanism by which the casein-chitosan flocculation is produced.

Chitosan is essentially a positively charged polysaccharide. Iron and calcium are cations. Anal et al. [153] measured zeta potential of chitosan solutions, sodium caseinate solutions and chitosan-caseinate mixtures in a range of $\mathrm{pH}$ (3.0-6.5). They found that the pure chitosan solutions were strongly positively charged between $\mathrm{pH} 3.0$ and 6.0. The zeta potential values of chitosan solutions decreased with increasing $\mathrm{pH}$ and were slightly negative (approximately $-2.5 \mathrm{mV}$ ) at $\mathrm{pH}$ 6.5. In our study, in the range of $\mathrm{pH}$ 3.0-6.0, isolated molecules of chitosan were probably interacting with iron or calcium by adsorption rather than by electrostatic forces. Besides, Anal et al. [153] observed that the zeta potentials of the chitosan-caseinate solutions were negative at $\mathrm{pH}>5.5$. In this range of $\mathrm{pH}$, in our work, electrostatic interaction could exist between chitosan-caseinate complexes and iron or calcium. However, when chitosan precipitates, it captures the iron or calcium either by electrostatic forces or by adsorption $[138,139]$.

The behavior of chitosan with calcium and iron in the digestive simulations were similar and can be explained in the same manner. However, the behavior between the other fibers used and the same micronutrients in the digestive simulations were significantly different. The flocculus formation by chitosan is a very strong kind of behavior which is independent of the use of the dialysis membrane. Evidently other types of interactions are brought into play for the other fibers that need further studies to determine them.

\section{Conclusion}

Results showed that the different plant fibers decreased glucose, calcium and iron availabilities whereas the effect of chitosan (fiber from animal source) was more pronounced. These findings could be positive or negative depending on the nutrient and the nutritional stage or health of the population who would receive the food under study. However, the in vitro digestive chemical experimental model may be used to increase the understanding of the interactions between animal and plant fibers with nutrients and micronutrients. This knowledge is very important from the point of view of health and for food industry and technologists. 


\section{Author details}

Marina Dello Staffolo

CIDCA (Centro de Investigación y Desarrollo en Criotecnología de Alimentos), CONICET-CCT La Plata, Fac. Cs. Exactas, Universidad Nacional de La Plata, La Plata, Argentina

Alicia E. Bevilacqua

CIDCA (Centro de Investigación y Desarrollo en Criotecnología de Alimentos), CONICET-CCT La

Plata, Fac. Cs. Exactas, Universidad Nacional de La Plata, La Plata, Argentina

Departamento de Ingeniería Química, Facultad de Ingeniería, UNLP

María Susana Rodríguez and Liliana Albertengo

Instituto de Química del Sur (INQUISUR), CO NICET-UNS Bahía Blanca, Departamento de

Química, Universidad Nacional del Sur, Argentina

\section{Acknowledgement}

Financial support from CONICET and SeCyT-Universidad Nacional del Sur is gratefully acknowledged. Marina Dello Staffolo and Alicia Bevilacqua express their gratitude to Universidad Nacional de La Plata and bamboo, inulin and wheat suppliers (Imperial Sensus, CFF and JRS).

\section{References}

[1] Green CJ. Fiber in enteral nutrition. South African Journal of Clinical Nutrition 2000;13(4) 150-160.

[2] Food and Nutrition Board, Institute of Medicine (2001). Dietary reference intakes. Proposed definition of dietary fiber. A report of the panel on the definition of dietary fiber and the standing committee on the scientific evaluation of dietary reference intakes. Washington, DC: National Academy Press.

[3] Thebaudin JY., Lefebvre AC.,Harrington M., Bourgeois CM. Dietary fibres: Nutritional and technological interest. Trends in Food Science \& Technology 1997;81 41-48.

[4] Tungland BC., Meyer D. Nondigestible oligo and polysaccharides (dietary fibre): their physiology and role in human health and food. Comprenhensive Reviews in Food Science and Food Safety 2002;1(3) 90-109.

[5] Trout D., Behall K., Osilesi O. Prediction of glycaemic index for starchy foods. American Journal of Clinical Nutrition 1993;58 873-878.

[6] Jenkins DJA., Kendall CWC., Axelsen M., Augustin LSA., Vuksan V. Viscous and nonviscous fibres, nonabsorbable and low glycaemic index carbohydrates, blood lipids and coronary heart disease. Current Opinion in Lipidology 2000;11(1) 49-56.

[7] Luccia BHD., Kunkel ME. In vitro availability of calcium from sources of cellulose, methylcellulose, and psyllium. Food Chemistry 2002;77 139-146. 
[8] Bosscher D., Van Ciaillie-Bertrand M., Deelstra H. Effect of thickening agents, based on soluble dietary fibre on the availability of calcium, iron, and zinc from infants formulas. Nutrition 2001;17 614-618.

[9] Salas-Salvadó J., Martinez-González MA., Bulló M., Ros E. The role of diet in the prevention of type 2 diabetes. Nutrition, Metabolism \& Cardiovascular Diseases 2011;21, B32-B48.

[10] Nordin BEC. Calcium and Osteoporosis. Nutrition 1997;13 664-686.

[11] Fardellonea P., Cottéb F-E., Rouxc C., Lespessaillesd E., Merciere F., Gaudinf A-F. Calcium intake and the risk of osteoporosis and fractures in French women. Joint Bone Spine 2010;77 154-158.

[12] Beard J., Stoltzfus RJ. Iron-deficiency anemia: Reexamining the nature and magnitude of the public health problem. Journal of Nutrition 2001;131 563S-703S.

[13] Thompson SA., Weber CW. Influence of $\mathrm{pH}$ on the binding of copper, zinc and iron in six fiber sources. Journal of Food Science 1979;44 752-754.

[14] Laszlo JA. Mineral binding properties of soy hull. Modelling mineral interactions with an insoluble dietary fiber source. Journal of Agriculture and Food Chemistry 1987;35 593-600.

[15] Torre M., Rodriguez AR., Saura-Calixto F. Interactions of Fe(II), Ca(I1) and Fe(II1) with high dietary fibre materials: A physicochemical approach. Food Chemistry 1995;54 2331.

[16] Chau C-F., Chen C-H., Lin C-Yi. Insoluble fibre-rich fractions derived from Averrhoa carambola: Hypoglycemic effects determined by in vitro methods. LebensmittelWissenschaft und-Technologie 2004;37 331-335.

[17] Bosscher D., Van Caillie-Bertrand M., Van Cauwenbergh R., Deelstra H. Availabilities of calcium, iron, and zinc from dairy infant formulas is affected by soluble dietary fibres and modified starch fractions. Nutrition 2003;19 641-645.

[18] Argyri K., Birba A., Miller DD., Komaitis M., Kapsokefalou M. Predicting relative concentrations of bioavailable iron in foods using in vitro digestion: New developments. Food Chemistry 2009;113 602-607.

[19] Hur SJ., Lim BO., Decker EA., McClements DJ. In vitro human digestion models for food applications. Food Chemistry 2011;125 1-12.

[20] Laparra JM., Tako E., Glahn RP., Miller DD. Supplemental inulin does not enhance iron bioavailability to Caco-2 cells from milk- or soy-based, probiotic-containing, yoghurts but incubation at $37^{\circ} \mathrm{C}$ does. Food Chemistry 2008;109 122-128.

[21] Tamine A., Robinson R. Yoghurt Science and Technology, 3rd ed. Boca Raton: CRC Press; 2007.

[22] Hispley EH. Dietary 'fibre' and pregnancy toxaemia. British Medical Journal 1953;2 420422.

[23] Burkitt DP. The role of refined carbohydrate in large bowel behaviour and disease. Plant Foods for Man 1973;1 5-9.

[24] Trowell H. Atherosclerosis, Ischemic heart disease and dietary fiber. American Journal of Clinical Nutrition 1972;25 926-932. 
[25] Cummings TJ., Mann J., Nishida C., Vorster H. Dietary fibre: An agreed definition. Lancet 2009;373 365-366.

[26] Harris SS., Pijls L. Dietary fibre: Refining a definition. Lancet 2009;374 28.

[27] Phillips GO., Cui SW. An introduction: Evolution and finalisation of the regulatory definition of dietary. Food Hydrocolloid 2011;25 139-143.

[28] Elleuch M., Bedigian D., Roiseux O., Besbes S., Blecker C., Attia H. Dietary fibre and fibre-rich by-products of food processing: Characterization, technological functionality and commercial applications: A review. Food Chemistry 2011;124 411-421.

[29] Borderías AJ., Sánchez-Alonso I., Pérez-Mateos M. New application of fibre in foods: Addition to fishery products. Trends in Food Science and Technology 2005;16 458-465.

[30] Normand FL., Ory RL., Mod RR. Binding of bile acids and trace minerals by soluble hemicelluloses of rice. Food Technology 1987;41 86-99.

[31] Chawla R., Patil GR. Soluble Dietary Fiber. Comprenhensive Reviews in Food Science and Food Safety 2010;9 178-196.

[32] Jenkins DJA., Jenkins MJA., Wolever TMS., Taylor RH. Slow release carbohydrate: Mechanism of action of viscous fibers. Journal of Clinical Nutrition and Gastroenterology 1986;1 237-241.

[33] Dikeman CL., Fahey GCJr. Viscosity as Related to Dietary Fiber: A Review. Critical Reviews in Food Science and Nutrition 2006;46(8) 649-663.

[34] Lattimer J., Haub M. Effects of dietary fiber and its components on metabolic health. Nutrients 2010;2 1266-1289.

[35] Claye SS., Idouraine A., Weber CW. Dietary fibre, what it is and how it is measured. Food Chemistry 1996;57 305-310.

[36] Prosky L., Asp N-G., Scheweizer TF., DeVries JW., Furda I. Determination of insoluble and soluble, and total dietary fibre in foods and food products: Interlaboratory study. Journal of the Association of Official Analytical Chemists1988;71 1017-1023.

[37] Englyst HN., Quigley ME., Hudson GJ. Determination of dietary fiber as non-starch polysaccharides with gas-liquid chromatographic or spectrophotometric measurement of constituent sugars. Analyst 1994;119 1497-1509.

[38] Van Soest PJ. Use of detergents in the analysis of fibrous feeds II. Determination of plant cell-wall constituents. Journal of the Association of Official Analytical Chemistry 1963;48 829-835.

[39] Ripsin CM., Keenan JM., Jacobs DR., Elmer PJ., Welch RR., Van Horn L., Liu K., Turnbull WH., Thye FW., Kestin M., Hegsted M., Davidson DM., Davidson MH., Dugan LD., Demark-Wahnefried W., Beling S. Oat products and lipid lowering: a metaanalysis. Journal of the American Medical Association 1992;267 3317-3325.

[40] Olson BH., Anderson SM., Becker MP., Anderson JW., Hunninghake DB., Jenkins DJA., LaRosa JC., Rippe JM., Roberts DCK., Stoy DB., Summerbell CD., Truswell AS., Wolever TMS., Morris DH., Fulgoni VL. Psyllium-enriched cereals lower blood total cholesterol and LDL-cholesterol, but not HDL cholesterol, in hypercholesterolemic adults: results of a meta-analysis. Journal of Nutrition 1997;127 1973-1980.

[41] Anderson JW., Allgood LD., Lawrence A., Altringer LA., Jerdack GR., Hengehold DA., Morel JG. Cholesterol-lowering effects of psyllium intake adjunctive to diet therapy in 
men and women with hypercholesterolemia: meta-analysis of 8 controlled trials. American Journal of Clinical Nutrition 2000;71 472-479.

[42] Chau CF., Huang YL. Effects of the insoluble fiber derived from Passiflora edulis seed on plasma and hepatic lipids and fecal output. Molecular Nutrition \& Food Research 2005;49 786-790.

[43] Cho IJ., Lee C., Ha TY. Hypolipidemic effect of soluble fiber isolated from seeds of Cassiatora Linn in rats fed a high-cholesterol diet. Journal of Agriculture and Food Chemistry 2007;55 1592-1596.

[44] Chau CF., Huang YL., Lin CY. Investigation of the cholesterol-lowering action of insoluble fibre derived from the peel of Citrus sinensis L. cv. Liucheng. Food Chemistry 2004;87(3) 361-366.

[45] Phillips MC. Mechanisms of cholesterol-lowering effects of dietary insoluble fibres: Relationships with intestinal and hepatic cholesterol parameters. British Journal of Nutrition 2005;94 331-337.

[46] Gonzalez M., Rivas C., Caride B., Lamas A., Taboada C. Effects of orange and apple pectin on cholesterol concentration in serum, liver and faeces. Journal of Physiology and Biochemistry 1998;54(2) 99-104.

[47] Anttila H., Sontag-Strohm T., Salovaara H. Viscosity of $\beta$-glucan in oat products. Agricultural and Food Science 2004;13 80-87.

[48] Wood PJ. Relationships between solution properties of cereal $\beta$-glucans and physiological effects - A review. Trends in Food Science and Technology 2004;15 313320.

[49] Zacherl C., Eisner P., Engel K-H. In vitro model to correlate viscosity and bile acidbinding capacity of digested water-soluble and insoluble dietary fibres. Food Chemistry 2011;126 423-428.

[50] Galisteo M., Moron R., Rivera L., Romero R., Anguera A., Zarzuelo A. Plantago ovata husks-supplemented diet ameliorates metabolic alterations in obese Zucker rats through activation of AMP-activated protein kinase. Comparative study with other dietary fibers. Clinical Nutrition 2010;29 261-267.

[51] Delzenne NM., Kok N. Effects of fructans-type prebiotics on lipid metabolism. American Journal of Clinical Nutrition 2001;73 456S-458S.

[52] Eshak ES., Iso H., Date C., Kikuchi S., Watanabe Y., Wada Y., Tamakoshi A. and the JACC Study Group. Dietary fiber intake is associated with reduced risk of mortality from cardiovascular disease among Japanese men and women. Journal of Nutrition 2010;140 1445-1453.

[53] Health claims: fruits, vegetables, and grain products that contain fiber, particularly soluble fiber, and risk of coronary heart disease. Code of Federal Regulations 2010;Secc. $101,77$.

[54] Kaczmarczyka MM., Michael J., Miller MJ., Freunda GG. The health benefits of dietary fiber: Beyond the usual suspects of type 2 diabetes mellitus, cardiovascular disease and colon cancer. Metabolism 2012, article in press. doi:10.1016/j.metabol.2012.01.017.

[55] Slavin JL. Dietary fiber and body weight. Nutrition 2005;21 411-418. 
[56] Wang ZQ., Zuberi AR., Zhang XH., Macgowan J., Qin J., Ye X. Effects of dietary fibers on weight gain, carbohydrate metabolism, and gastric ghrelin gene expression in mice fed a high-fat diet. Metabolism 2007;56 1635-1642.

[57] Choi JS., Kim H., Jung MH., Hong S., Song J. Consumption of barley $\beta$-glucan ameliorates fatty liver and insulin resistance in mice fed a high-fat diet. Molecular Nutrition \& Food Research 2010;54 1004-1013.

[58] Behall KM., Scholfield DJ., Hallfrisch JG., Liljeberg-Elmstahl HG. Consumption of both resistant starch and $\beta$-glucan improves postprandial plasma glucose and insulin in women. Diabetes Care 2006;29 976-81.

[59] Tucker LA., Thomas KS. Increasing total fiber intake reduces risk of weight and fat gains in women. Journal of Nutrition 2009;139 576-581.

[60] Birketvedt GS., Shimshi M., Erling T., Florholmen J. Experiences with three different fiber supplements in weight reduction. Medical Science Monitor 2005; 11 I5-I8.

[61] Barclay AW., Petocz P., McMillan-Price J., Flood VM., Prvan T., Mitchell P. Glycemic index, glycemic load, and chronic disease riskea meta-analysis of observational studies. American Journal of Clinical Nutrition 2008;87 627-637.

[62] Sluijs I., van der Schouw YT., van der A DL., Spijkerman AM., Hu FB., Grobbee DE., Beulens JW. Carbohydrate quantity and quality and risk of type 2 diabetes in the European Prospective Investigation into Cancer and Nutrition-Netherlands (EPIC-NL) study. American Journal of Clinical Nutrition 2010;92 905-911.

[63] Anderson JW., Baird P., Davis RH Jr., Ferreri S., Knudtson M., Koraym A., Waters V., Williams CL. Health benefits of dietary fiber. Nutrition Review 2009;67 188-205.

[64] Salmerón J., Ascherio A., Rimm EB., Colditz GA., Spiegelman D., Jenkins DJ. Dietary fiber, glycemic load, and risk of NIDDM in men. Diabetes Care 1997;20 545-550.

[65] Salmerón J, Manson JE, Stampfer MJ, Colditz GA, Wing AL, Willett WC. Dietary fiber, glycemic load and risk of non-insulin-dependent diabetes mellitus in women. Journal of the American Medical Association 1997;277 472-477.

[66] Sierra M., Garcia JJ., Fernandez N., Diez MJ., Calle AP. Therapeutic effects of psyllium in type 2 diabetic patients. European Journal of Clinical Nutrition 2002;56 830-842.

[67] Chandalia M., Garg A., Lutjohann D., von Bergmann K., Grundy SM., Brinkley LJ. Beneficial effects of high dietary fiber intake in patients with type 2 diabetes mellitus. The New England Journal of Medicine 2000;342 1392-1398.

[68] Salas-Salvadó J., Farrés X., Luque X., Narejos S., Borrell M., Basora J. Fiber in ObesityStudy Group. Effect of two doses of a mixture of soluble fibres on body weight and metabolic variables in overweight or obese patients: a randomised trial. British Journal of Nutrition 2008;99 1380-1387.

[69] Weickert MO., Mohlig M., Koebnick C., Holst JJ., Namsolleck P., Ristow M. Impact of cereal fibre on glucose-regulating factors. Diabetologia 2005;48 2343-2353.

[70] Raninen K., Lappi J., Mykkanen H., Poutanen K. Dietary fiber type reflects physiological functionality: comparison of grain fiber, inulin, and polydextrose. Nutrition Review 2011;69 9-21. 
[71] Lairon D., Play B., Jourdheuil-Rahmani D. Digestible and indigestible carbohydrates: interactions with postprandial lipid metabolism. Journal of Nutrition Biochemistry 2007; 18 217-27.

[72] Anderson JW., Chen WJ. Plant fiber. Carbohydrate and lipid metabolism. American Journal of Clinical Nutrition 1979;32 346-363.

[73] Naslund E., Bogefors J., Skogar S., Gryback P., Jacobsson H., Holst JJ. GLP-1 slows solid gastric emptying and inhibits insulin, glucagon, and PYY release in humans. American Journal of Physiology 1999;277 R910-R916.

[74] Reimer RA., Grover GJ., Koetzner L., Gahler RJ., Lyon MR., Wood S. The soluble fiber complex PolyGlycopleX lowers serum triglycerides and reduces hepatic steatosis in high-sucrose fed rats. Nutrition Research 2011;31 296-301.

[75] Massimino SP., McBurney MI., Field CJ., Thomson AB., Keelan M., Hayek MG. Fermentable dietary fiber increases GLP-1 secretion and improves glucose homeostasis despite increased intestinal glucose transport capacity in healthy dogs. Journal of Nutrition 1998;128 1786-93.

[76] Delzenne NM, Cani P. Nutritional modulation of gut microbiota in the context of obesity and insulin resistance: potential interest of prebiotics. International Dairy Journal 2010;20 277-280.

[77] Eckburg PB., Bik EM., Bernstein CN., Purdom E., Dethlefsen L., Sargent M. Microbiology: diversity of the human intestinal microbial flora. Science 2005; 308 16351638.

[78] Sghir A., Gramet G., Suau A., Rochet V., Pochart P., Dore J. Quantification of bacterial groups within human fecal flora by oligonucleotide probe hybrid-ization. Applied and Environmental Microbiology 2000; 66(5) 2263-2266.

[79] Muller CA., Autenrieth IB., Peschel A. Innate defenses of the intestinal epithelial barrier. Cellular and Molecular Life Sciences 2005; 62(12) 1297-1307.

[80] Macfarlane, GT., Macfarlane S. Human colonic microbiota: ecology, physiology and metabolic potential of intestinal bacteria. Scandinavian Journal of Gastroenterology 1997; Supplement 32(222) 3-9.

[81] Cook SI., Sellin JH. Review article: short chain fatty acids in health and disease. Alimentary Pharmacology and Therapeutics 1998;12(6) 499-507.

[82] Mazur WM., Duke JA., Wahala K., Rasku S., Adlercreutz H. Isoflavonoids and lignans in legumes: nutritional and health aspects in humans. Journal of Nutritional Biochemistry 1998;9(4) 193-200.

[83] Rowland I., Faughnan M., Hoey L., Wahala K., Williamson G., Cassidy A. Bioavailability of phyto-oestrogens. British Journal of Nutrition 2003, 89(Suppl. 1) 4558.

[84] Brownlee IA. The physiological roles of dietary fibre. Food Hydrocolloids 2011;25 238250.

[85] Terada A., Hara H., Mitsuoka T. Effect of dietary alginate on the faecal microbiota and faecal metabolic activity in humans. Microbial Ecology in Health and Disease 1995;8(6) 259-266. 
[86] Terada, A., Hara, H., Sato, D., Higashi, T., Nakayama, S., Tsuji, K. Effect of dietary chitosan on faecal microbiota and faecal metabolites of humans. Microbial Ecology in Health and Disease 1995;8(1) 15-21.

[87] Grasten S., Liukkonen KH., Chrevatidis A., El-Nezami H., Poutanen K., Mykkanen H. Effects of wheat pentosan and inulin on the metabolic activity of fecal microbiota and on bowel function in healthy humans. Nutrition Research 2003;23(11) 1503-1514.

[88] Bittner AC., Croffut RM., Stranahan MC., Yokelson TN. Prescriptassist probioticprebiotic treatment for irritable bowel syndrome: an open- label, partially controlled, 1year extension of a previously published controlled clinical trial. Clinical Therapeutics 2007;29 (6) 1153-1160.

[89] Fujimori S., Gudis K., Mitsui K., Seo T., Yonezawa M., Tanaka S. A randomized controlled trial on the efficacy of synbiotic versus probiotic or prebiotic treatment to improve the quality of life in patients with ulcerative colitis. Nutrition 2009;25(5) 520525.

[90] Molist F., de Segura AG., Gasa J., Hermes RG., Manzanilla EG., Anguita M. Effects of the insoluble and soluble dietary fibre on the physicochemical properties of digesta and the microbial activity in early weaned piglets. Animal Feed Science and Technology 2009;149(3-4) 346-353.

[91] Noriega L., Cuevas I., Margolles A., de los Reyes-Gavilán CG. Deconjugation and bile salts hydrolase activity by Bifidobacterium strains with acquired resistance to bile. International Dairy Journal 2006;16(8) 850-855.

[92] Klaver FA., van der Meer R. The assumed assimilation of cholesterol by Lactobacilli and Bifidobacteriu $\mathrm{m}$ bifidum is due to their bile salt-deconju gating activity. Applied and Environmental Microbiology 1993;59 1120-1124.

[93] Tahri K., Grill JP., Schneider F. Bifidobacteri a strain behaviour toward cholestero 1: coprecipita tion with bile salts and assimilation. Current Microbiology 1996;33 187-93.

[94] Pereira DI., Gibson GR. Cholesterol assimilat ion by lactic acid bacteria and bifidobacteria isolated from the human gut. Applied and Environmental Microbiology 2002;68 4689-4693.

[95] Demigne C., Morand C., Levrat MA., Besson C., Moundras C., Remesy C. Effect of propionate on fatty acid and cholesterol synthesis and on acetate metabolism in isolated rat hepatocytes. British Journal of Nutrition 1995;74 209-219.

[96] Nagler-Anderson C. Man the barrier! Strategic defences in the intestinal mucosa. Nature Reviews Immunology 2001;1(1) 59-67.

[97] Strugala V., Allen A., Dettmar PW. Pearson JP. Colonic mucin: methods of measuring mucus thickness. Proceedings of the Nutrition Society 2003; 62(1) 237-243.

[98] Taylor C., Allen A., Dettmar PW., Pearson JP. Two rheologically different gastric mucus secretions with different putative functions. Biochimica et Biophysica Acta - General Subjects 2004;1674(2) 131-138.

[99] Watzl B., Girrbach S., Roller M. Inulin, oligofructose and immunomodulation. British Journal of Nutrition 2005;93(Supp) S49-S55. 
[100] Field CJ., McBurney MI., Massimino S., Hayek MG., Sunvold GD. The fermentable fiber content of the diet alters the function and composition of canine gut associated lymphoid tissue. Veterinary Immunology and Immunopathology 1999;72(3-4) 325-341.

[101] Wismar R., Brix S., Frokiaer H., Laerke HN. Dietary fibers as immunoregulatory compounds in health and disease. Annals of the New York Academy of Sciences 2010;1190 70-85.

[102] Brownlee IA., Dettmar PW., Strugala V., Pearson JP. The interaction of dietary fibres with the colon. Current Nutrition and Food Science 2006;2(3) 243-264.

[103] Parker SL., Tong T., Bolden S., Wingo PA. Cancer Statistics. CA- A Cancer Journal for Clinicians 1997;47 5-27.

[104] Bingham SA., Day NE., Luben R., Ferrari P., Slimani N., Norat T., Clavel-Chapelon F., Kesse E., Nieters A., Boeing H., Tjønneland A., Overvad K., Martinez C., Dorronsoro M., Gonzalez, C.A., Key TJ., Trichopoulou A., Naska A., Vineis P., Tumino R., Krogh V., Bueno-de-Mesquita HB., Peeters PHM., Berglund G., Hallmans G., Lund E., Skeie G., Kaaks R., Riboli E. Dietary fibre in food and protection against colorectal cancer in the European Prospective Investigation into Cancer and Nutrition (EPIC): an observational study. The Lancet 2003;361 1496-1501.

[105] Dahm CC., Keogh RH., Spencer EA., Greenwood DC., Key TJ., Fentiman IS, Shipley MJ., Brunner EJ., Cade JE., Burley VJ., Mishra G., Stephen AM., Kuh D., White IR., Luben R., Lentjes MAH., Khaw KT, Bingham SA. Dietary Fiber and colorectal cancer risk: A Nested case-control Study Using Food Diaries. Journal of the National Cancer Institute 2010;102(9) 614-626.

[106] Health claims: fruits, vegetables, and grain products that contain fiber, particularly soluble fiber, and risk of coronary heart disease. Code of Federal Regulations 2010;101.77.

[107] Reddy BS., Engle A., Simi B., Goldman M. Effect of dietary fiber on colonic bacterial enzymes and bile acids in relation to colon cancer. Gastroenterology 1992;102 1475-1482.

[108] Reddy BS. Dietary fiber and colon cancer: animal model studies. Pre-Med Journal 1995;6 559-565.

[109] Roediger WEW. Utilization of nutrients by isolated epithelial cells of rat colon. Gastroenterology 1982;83 424-429.

[110] Kim YS., Tsao D., Siddiqui B., Whitehead JS., Arnstein P., Bennett J., Hicks J. Effects of sodium butyrate and dimethylsulfoxide on biochemical properties of human colon cancer cells. Cancer 1980;45 1185-1192.

[111] Hague A., Manning AM., Haneon KA., Huschstscha LL., Hart D., Paraskeva C. Sodium butyrate induces apoptosis in human colonic tumour cell lines in a p53independent pathway implications for the possible role of dietary fibre in the prevention of large-bowel cancer. International Journal of Cancer 1993;55 498-505.

[112] Harris PJ., Roberton AM., Hollands HJ., Ferguson LR. Adsorption of a hydrophobic mutagen to dietary fibre from the skin and flesh of potato tubers. Mutation Research 1991;260 203-213. 
[113] Harris PJ., Triggs CM., Roberton AM., Watson ME., Ferguson LR. The adsorption of heterocyclic aromatic amines by model dietary fibres with contrasting compositions. Chemico-Biological Interactions 1996;100 13-25.

[114] Ferguson LR., Roberton AM., Watso ME., Kestell P., Harris PJ. The adsorption of a range of dietary carcinogens by $\alpha$-cellulose, a model insoluble dietary fiber. Mutation Research. 1993;319 257-266.

[115] Halliwell B., Zhao K., Whiteman M. The gastrointestinal tract: a major site of antioxidant action? Free Radical Research 2000;33 819-830.

[116] Gee JM., Johnson IT. Polyphenolic compounds: interactions with the gut and implications for human health. Current Medicinal Chemistry 2001;8 1245-1255.

[117] Mälki Y. Trends en dietary fiber research and development: a review. Acta Alimentaria 2004;33(1) 39-62.

[118] Schneeman BO. Gastrointestinal physiology and functions. British Journal of Nutrition 2002;88(2) S159-S163.

[119] Hersey SJ., Sachs G. Gastric acid secretion. Physiological Reviews 1995;75(1) 155-189.

[120] Sternini C., Anselmi L., Rozengurt E. Enteroendocrine cells: a site of 'taste' in gastrointestinal chemosensing. Current Opinion in Endocrinology, Diabetes and Obesity 2008;15(1) 73-78.

[121] Furness JB. Types of neurons in the enteric nervous system. Journal of the Autonomic Nervous System 2000;81(1-3) 87-96.

[122] Pedersen AM., Bardow A., Jensen SB., Nauntofte B. Saliva and gastrointestinal functions of taste, mastication, swallowing and digestion. Oral Diseases 2002;8(3) 117129.

[123] Embleton JK., Pouton CW. Structure and function of gastro-intestinal lipases. Advanced Drug Delivery Reviews 1997;25(1) 15-32.

[124] Miled N., Canaan S., Dupuis L., Roussel A., Riviere M., Carriere F. Digestive lipases: from three-dimensional structure of physiology. Biochimie 2000;82(11) 973-986.

[125] Chaplin, MF. Fibre and water binding. Proceedings of the Nutrition Society 2003;62(1) 223-227.

[126] Holt S., Heading RC., Carter DC. Effect of gel fibre on gastric emptying and absorption of glucose and paracetamol. Lancet 1979;1(8117) 636-639.

[127] Sanaka M., Yamamoto T., Anjiki H., Nagasawa K., Kuyama Y. Effects of agar and pectin on gastric emptying and post-prandial glycaemic profiles in healthy human volunteers. Clinical and Experimental Pharmacology and Physiology 2007;34(11) 11511155.

[128] Benini L., Castellani G., Brightenti F., Heaton KW., Brentegani MT., Casiraghi MC. Gastric emptying of a solid meal is accelerated by the removal of dietary fibre naturally present in food. Gut 1995;36(6) 825-830.

[129] Kimura Y., Watanabe K., Okuda H. Effects of soluble sodium alginate on cholesterol excretion and glucose tolerance in rats. Journal of Ethnopharmacology 1996;54(1) 47-54.

[130] Torsdottir I., Alpsten M., Holm G., Sandberg AS., Tolli J. A small dose of soluble alginate-fiber affects postprandial glycemia and gastric emptying in humans with diabetes. Journal of Nutrition 1991;121(6) 795-799. 
[131] Fairchild RM., Ellis PR., Byrne AJ., Luzio SD., Mir MA. A new breakfast cereal containing guar gum reduces postprandial plasma glucose and insulin concentrations in normal-weight human subjects. British Journal of Nutrition 1996;76(1) 63-73.

[132] Sierra M., Garcia JJ., Fernandez N., Diez MJ., Calle AP., Sahagún AM. Effects of ispaghula husk and guar gum on postprandial glucose and insulin concentrations in healthy subjects. European Journal of Clinical Nutrition 2001;55(4) 235-243.

[133] Behall KM., Scholfield DJ., Hallfrisch JG. Barley $\beta$-glucan reduces plasma glucose and insulin responses compared with resistant starch in men. Nutrition Research 2006;26(12) 644-650.

[134] Jenkins AL., Jenkins DJA., Zdravkovic U., Wulrsch P., Vuksan V. Depression of the glycemic index by high levels of $\beta$-glucan fiber in two functional foods tested in type 2 diabetes. European Journal of Clinical Nutrition 2002;56(7) 622-628.

[135] Tosh SM., Brummer Y., Wolever TMS., Wood PJ. Glycemic response to oat bran muffins treated to vary molecular weight of $\beta$-glucan. Cereal Chemistry 2008;85(2) 211217.

[136] Boisen S., Eggum BO. Critical evaluation of in vitro methods for estimating digestibility in simple-stomach animals. Nutrition Research Reviews 1991;4 141-162.

[137] Coles LT., Moughan PJ., Darragh AJ. In vitro digestion and fermentation methods, including gas production techniques, as applied to nutritive evaluation of foods in the hindgut of humans and other simple stomached animals. Animal Food Science and Technology 2005;123 421-444.

[138] Rodríguez MS., Montero M., Dello Staffolo M., Martino M., Bevilacqua A., Albertengo L. Chitosan influence on glucose and calcium availability from yoghurt: In vitro comparative study with plants fibre. Carbohydrate Polymers 2008;74 797-801.

[139] Dello Staffolo M., Martino M., Bevilacqua A., Montero M., Rodríguez MS., Albertengo L. Chitosan Interaction with Iron from Yoghurt Using an In Vitro Digestive Model: Comparative Study with Plant Dietary Fibers. International Journal of Molecular Science 2011;12 4647-4660.

[140] Total, soluble, and insoluble dietary fibre in foods. AOAC Official Methods 991.43. In: Cunniff P. (ed.) Official Methods of Analysis (16th ed.); Arlington: AOAC International; 1995. p7-9.

[141] Robertson JB., Van Soest PJ. The detergent system of analysis and its applications to human foods. In: James WPT., Theander O., (eds.) The Analysis of Dietary Fiber and Food. New York: Marcel Dekker; 1981. p139-153.

[142] Dello Staffolo M., Bertola N., Martino M., Bevilacqua A. Influence of dietary fibre addition on sensory and rheological properties of yoghurt. International Dairy Journal 2004;14 263-268.

[143] Fernández-García E., McGregor JU. Fortification of sweetened plain yoghurt with insoluble dietary fibre. European Food Research and Technology 1997;204, 433-437.

[144] Kumar MNVR., Muzzarelli RAA., Muzzarelli C., Sashiwa H., Domb AJ. Chitosan chemistry and pharmaceutical perspectives. Chemical Reviews 2004;104 6017-6084. 
[145] Gorinstein S., Zachwieja Z., Folta M., Barton H., Piotrowicz J., Zember M., Comparative content of dietary fiber, total phenolics, and minerals in persimmons and apples. Journal of Agricultural and Food Chemistry 2001;49 952-957.

[146] Van Craeyveld V., Delcour JA., Courtin CM. Extractability and chemical and enzymic degradation of psyllium (Plantago ovata Forsk) seed husk arabinoxylans. Food Chemistry 2009;112 812-819.

[147] Sudha ML., Baskaran V., Leelavathi K. Apple pomace as a source of dietary fiber and polyphenols and its effect on the rheological characteristics and cake making. Food Chemistry 2007;104 686-692.

[148] Dierenfeld ES., Hintz HF., Robertson JB., van Soest PJ., Oftedal OT. Utilization of bamboo by the giant panda. Journal of Nutrition 1982;112 636-641.

[149] Escarnot E., Agneessens R., Wathelet B., Paquot M. Quantitative and qualitative study of spelt and wheat fibres in varying milling fractions. Food Chemistry 2010;122 857-863.

[150] Sun-Waterhouse D., Farr J., Wibisono R., Saleh Z. Fruit-based functional foods I: Production of food-grade apple fibre ingredients. International Journal Food Science and Technology 2008;43 2113-2122.

[151] Chan JKC., Wypyszyk VA. Forgotten natural dietary fiber: Psyllium mucilloid. Cereal Food. World 1988;33 919-922.

[152] Fischer MH., Yu N., Gray GR., Ralph J., Andersond L., Marletta JA. The gel-forming polysaccharide of psyllium husk (Plantago ovata Forsk). Carbohydrate Research 2004; 339 2009-2017.

[153] Anal AK., Tobiassen A., Flanagan J., Singh H. Preparation and characterization of nanoparticles formed by chitosan-caseinate interactions. Colloids and Surfaces B: Biointerfaces 2008;64 104-110.

[154] Reinhold JG., Faradji B., Abadi P., Ismail-Beigi F. Decreased absorption of calcium, magnesium, zinc and phosphorus by humans due to increased fibre and phosphorus consumption of wheat bread. Journal Nutrition 1976;106 493-503.

[155] Vitali D., Dragojević IV., Šebečić B., Vujić L. Impact of modifying tea-biscuit composition on phytate levels and iron content and availability. Food Chemistry 2007;102 82-89.

[156] Deuchi K., Kanauchi O., Shizukuishi M., Kobayashi E. Continuous and massive intake of chitosan affects mineral and fat-soluble vitamin status in rats fed on a high-fat diet. Bioscience Biotechnology and Biochemist 1995;59 1211-1216.

[157] Yang CY., Oh TW., Nakajima D., Maeda A., Naka T., Kim CS. Effects of habitual chitosan intake on bone mass, bone-related metabolic markers and duodenum CaBP D9K mRNA in ovariectomized SHRSP rats. Journal of Nutritional Science and Vitaminology 2002;48 371-378.

[158] Miret S., Simpson RJ., McKie AT. Physiology and molecular biology of dietary iron absorption. The Annual Review of Nutrition 2003;23 283-301.

[159] Bouhallab S., Bouglé D. Biopeptides of milk: Caseinophosphopeptides and mineral bioavailability. Reproduction Nutrition Development 2004;44 493-498. 
[160] Van den Heuvel EG., Schaafsma G., Muys T., van Dokkum W. Nondigestible oligosaccharides do not interfere with calcium and nonheme-iron absorption in young, healthy men. American Journal of Clinical Nutrition 1998;67 445-451.

[161] Azorín-Ortuño M., Urbán C., Cerón JJ., Tecles F., Allende A., Tomás-Barberán FA., Espín JC. Effect of low inulin doses with different polymerisation degree on lipid metabolism, mineral absorption, and intestinal microbiota in rats with fatsupplemented diet. Food Chemistry 2009; 113 1058-1065.

[162] Ausar SF., Bianco ID., Badini RG., Castagna LF., Modesti NM., Landa CA, Beltramo DM. Characterization of casein micelle precipitation by chitosans. Journal of Dairy Science 2001;84 361-369. 